United States Department of Energy

Office of Energy Research

Office of Basic Energy Sciences

Carbon Dioxide Research Division

Under Contract No. DE-AC06-76RL01830

\title{
TR045
}

\section{A Preliminary Analysis of U.S. CO2 Emissions Reduction Potential from Energy Conservation and the Substitution of Natural Gas for Coal in the Period to 2010}

\section{DO NOT MICROFILM COVER}

$010220 ?$ 


\section{DISCLAIMER}

This report was prepared as an account of work sponsored by an agency of the United States Government. Neither the United States Government nor any agency Thereof, nor any of their employees, makes any warranty, express or implied, or assumes any legal liability or responsibility for the accuracy, completeness, or usefulness of any information, apparatus, product, or process disclosed, or represents that its use would not infringe privately owned rights. Reference herein to any specific commercial product, process, or service by trade name, trademark, manufacturer, or otherwise does not necessarily constitute or imply its endorsement, recommendation, or favoring by the United States Government or any agency thereof. The views and opinions of authors expressed herein do not necessarily state or reflect those of the United States Government or any agency thereof. 


\section{DISCLAIMER}

Portions of this document may be illegible in electronic image products. Images are produced from the best available original document. 
This report has been reproduced directly from the best available copy.

Available from the National Technical Information Service, U. S. Department of Commerce, Springfield, Virginia 22161.

Price: Printed Copy A04

Microfiche A01

Codes are used for pricing all publications. The code is determined by the number of pages in the publication. Information pertaining to the pricing codes can be found in the current issues of the following publications,- which are generally available in most libraries: Energy Research Abstracts, (ERA); Government Reports Announcements and Index (GRA and I); Scientific and Technical Abstract Reports (STAR); and publication, NTIS-PR-360 available from (NTIS) at the above address.

\section{DO NOT MICROFILM
COVER}


Prepared for

United States Department of Energy

Office of Energy Research

Office of Basic Energy Sciences

Carbon Dioxide Research Division
DOE/NBB-0085

Dist. Category UC-11

$\mathrm{DOE} / \mathrm{NBB}--0085$

Washington, D.C. 20545

DE89 008331

\section{TR045}

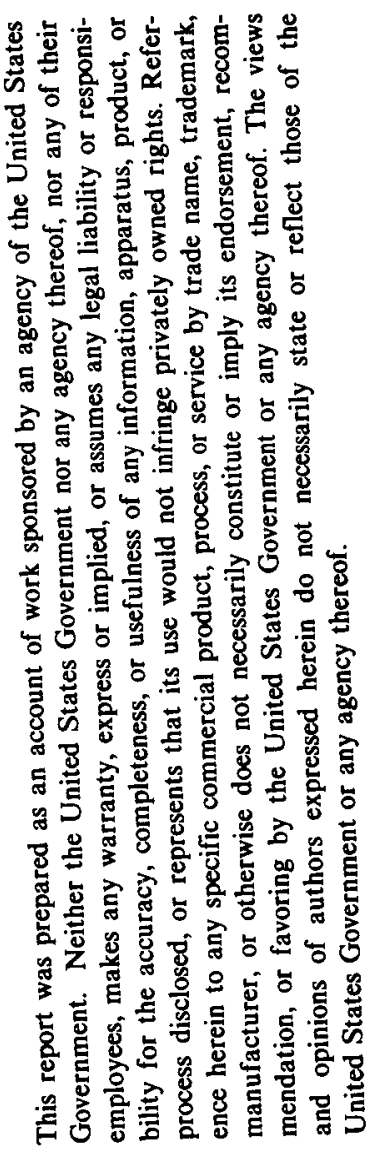

\section{A Preliminary Analysis of U.S. CO2 Emissions Reduction Potential from Energy Conservation and the Substitution of Natural Gas for Coal in the Period to 2010}

Prepared by:

J.A. Edmonds, W.B. Ashton

Pacific Northwest Laboratory

Washington, DC 20024

and

H.C. Cheng, M. Steinberg

Brookhaven National Laboratory

Upton, NY 11973

Under Contract No. DE-AC06-76RL01830 


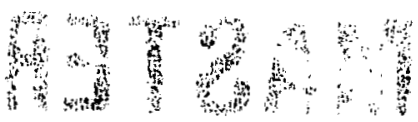




\section{EXECUTIVE SUMMARY}

Carbon dioxide $\left(\mathrm{CO}_{2}\right)$ is a product of burning fossil fuels (0il, gas and coal) and fossil fuel burning is the dominant source of global $\mathrm{CO}_{2}$ emissions amounting to 5.2 petagrams of carbon per year $(\mathrm{PgC})$ in 1985. The control of $\mathrm{CO}_{2}$ emissions would require control of energy production and use. U.S. emissions were $1.25 \mathrm{PgC}$ in 1985. National Energy Policy Plan (NEPP) projections show total U.S. emissions rising $38 \%$ by 2010 to $1.7 \mathrm{PgC}$.

Distribution of U.S. $\begin{array}{r}1985 \text { and NEPP } 2010 \text { Forecast } \\
\text { by Sector and Fuel }\end{array}$
\begin{tabular}{lccccr} 
Fuel & $\frac{1985}{45 \%}$ & $\frac{2010}{34 \%}$ & Sector & 1985 & $\frac{2010}{\text { Residential/ }}$ \\
\hline $0 i 1$ & $20 \%$ & $14 \%$ & Commercial & $13 \%$ & $10 \%$ \\
Gas & $35 \%$ & $52 \%$ & Industrial & $20 \%$ & $19 \%$ \\
Coal & & & Transport & $32 \%$ & $25 \%$ \\
& & & Utilities & $35 \%$ & $44 \%$
\end{tabular}

The U.S. Department of Energy (DOE) Carbon Dioxide Research Division (CDRD) has sponsored research at the Pacific Northwest Laboratory (PNL), Brookhaven National Laboratory (BNL), and at the Oak Ridge National Laboratory to do a preliminary assessment of the technical feasibility and consequences of reducing U.S. $\mathrm{CO}_{2}$ emissions from 1985 levels by 10,25 or 50 percent by either the year 1995 or 2010. In addition, DOE/CDRD sponsored a day-long roundtable attended by nine experts in the field to discuss this issue. Two methods of $\mathrm{CO}_{2}$ emissions reduction were considered: energy intensity reductions (conservation), and substitution of natural gas for coal. The study did not address the contribution of other energy supply options or the feasibility of pre- or post-combustion C02 removal. Furthermore, the study made no attempt to explore specific policies that might be employed to achieve technically feasible $\mathrm{CO}_{2}$ emissions reductions. This is not a policy document.

Six assessment tasks were performed. After a reference forecast was developed from NEPP, $\mathrm{CO}_{2}$ emissions reduction targets were established based on 1985 emissions rates. These are displayed below:

\begin{tabular}{|c|c|c|}
\hline $\begin{array}{l}\text { Percentage } \\
\text { Reduction } \\
\text { From } 1985\end{array}$ & $\begin{array}{l}\text { Maximum U.S. } \\
\mathrm{CO}_{2} \text { Emission }\end{array}$ & $\begin{array}{l}\mathrm{CO} 2 \text { Reduction from NEPP } \\
2010 \text { Forecast ( } 1.7 \mathrm{PgC}) \\
\text { to Meet Emissions Target }\end{array}$ \\
\hline $\begin{array}{r}0 \% \\
10 \% \\
25 \% \\
50 \%\end{array}$ & $\begin{array}{l}1.25 \mathrm{PgC} \\
1.13 \mathrm{PgC} \\
0.94 \mathrm{PgC} \\
0.63 \mathrm{PgC}\end{array}$ & $\begin{array}{l}28 \% \\
35 \% \\
46 \% \\
64 \%\end{array}$ \\
\hline
\end{tabular}

Conservation potential studies were then examined to see what energy and conservation efficiency improvements are feasible at current and anticipated energy technologies and prices. Studies included the Office of Energy Conservation annual multi-year plan, a recently released Energy Research Advisory Board (ERAB) report on U.S. energy competitiveness, the National Energy Policy Plan (NEPP) report, a recent American Council For An EnergyEfficient Economy (ACEEE) report on energy efficiency, and a World Resources 
Institute (WRI) report on energy intensity improvements for the year 2020. In addition, an analys is of recent energy efficiency trends and independent engineering studies of potential energy efficiency improvements were conducted in transportation and utilities by BNL. Fourth, the implications for the form of U.S. energy consumption were examined.

The potential for $\mathrm{CO}_{2}$ emissions reductions through the substitution of natural gas for coal was studied by examining potential natural gas availability, new natural gas electric power generation technologies, and the cost of coal and natural gas as industrial fuels.

The pertinence and timeliness of this work were underlined when the Toronto Conference on The Changing Atmosphere: Implications for Global Security was held. The Conference Statement called on governments and industry to reduce $\mathrm{CO}_{2}$ emissions by "approximately 20 percent of 1988 levels by the year 2005 as an initial global goal."

This study reached the following conclusions:

1. Under business-as-usual scenarios U.S. $\mathrm{CO}_{2}$ emissions are likely to rise significantly from present levels. Both the NEPP Reference Case and NEPP High Efficiency Case forecast higher U.S. $\mathrm{CO}_{2}$ emissions in the period to 2010 .

2. The conservation potential studies we examined indicate that level U.S. $\mathrm{CO}_{2}$ emissions are achievable in the period to 2010 . Level U.S. $\mathrm{CO}_{2}$ emissions were achieved between 1975 and 1985.

3. Reductions in U.S. $\mathrm{CO}_{2}$ emissions of up to $40 \%$ may be technically feasible in the period to 2020, but would require a sustained rate of energy intensity reduction greater than that experienced in the period 1980 to 1985 if levels of GNP growth similar to those forecast in NEPP are to be achieved.

Achieving $\mathrm{CO}_{2}$ emissions reductions of $50 \%$ or more by the year 2010 appears very difficult and unlikely through energy conservation and the substitution of natural gas for coal. Table I gives the $\mathrm{CO}_{2}$ emissions implications of the studies examined. Note that the most optimistic of these studies anticipates sufficient conservation potential to reduce emissions by 40\% from 1985 levels by the year 2020, while other studies indicate lesser $\mathrm{CO}_{2}$ emissions reductions possible in the period to 2010 .

An earlier, DOE/CDRD sponsored study, showed that by the year 2050 forecast U.S. emissions of $3.4 \mathrm{PgC}$ could be reduced to $1.5 \mathrm{PgC}$. This required universal adoption of best available technologies to achieve the $56 \%$ reduction (59\% worldwide) from a scenario with no technological improvement from 1975 levels. Further, reductions, to as little as 1.2 $\mathrm{PgC}$, were achieved through the accelerated substitution of nuclear and solar electric power for fossil generated electricity (a 65\% U.S. emissions reduction and $68 \%$ worldwide). Only with these further reductions are 1985 emissions levels reached. These results are consistent with the conclusions of the present study. 
4. The costs of achieving energy conservation potential are not adequately addressed in the studies we examined. The costs of not achieving specified levels of energy conservation were also not analyzed. These studies are themselves preliminary and were generally not intended to address the $\mathrm{CO}_{2}$ issue.

5. The achievement of even the $10 \%$ reduction target requires a very different final consumption pattern from that NEPP forecast.

6. In the period to 2010 larger contributions to $\mathrm{CO}_{2}$ emissions reduction appear available through energy conservation than through the substitution of natural gas for coal. Both energy supply and energy demand technologies are necessary to reduce U.S. emissions at minimum cost.

7. Advanced natural gas fired turbine technologies can provide lower $\mathrm{CO}_{2}$ emissions for electric utilities than conventional coal fired steam power generation.

The direct substitution of conventional natural gas for coal in existing coal boilers is not an attractive option at current and NEPP forecasted energy prices, despite the fact that natural gas combustion yields approximately half the $\mathrm{CO}_{2}$ of coal combustion.

8. If the U.S. acted alone to hold emissions to 1985 levels, anticipated global emissions would continue to grow and be no more than $7 \%$ lower than without U.S. actions in the period 1995 to 2010 unless advanced conservation technologies were sufficiently attractive to be adopted internationally.

While this document is intended to shed some light on the issue of the U.S. $\mathrm{CO}_{2}$ emissions reduction potential in the period to 2010 , from energy conservation and the substitution of natural gas for coal, it is only a start. Other work within the U.S. Department of Energy is underway and should result in further progress in understanding the potential feasibility and cost of reducing U.S. greenhouse gas emissions in both the near and long-terms. 
Table I: Historical $\mathrm{CO}_{2}$ Emissions and Those Associated With Various Energy Intensity Reduction Studies

$(\mathrm{PgC} / \mathrm{yr})$

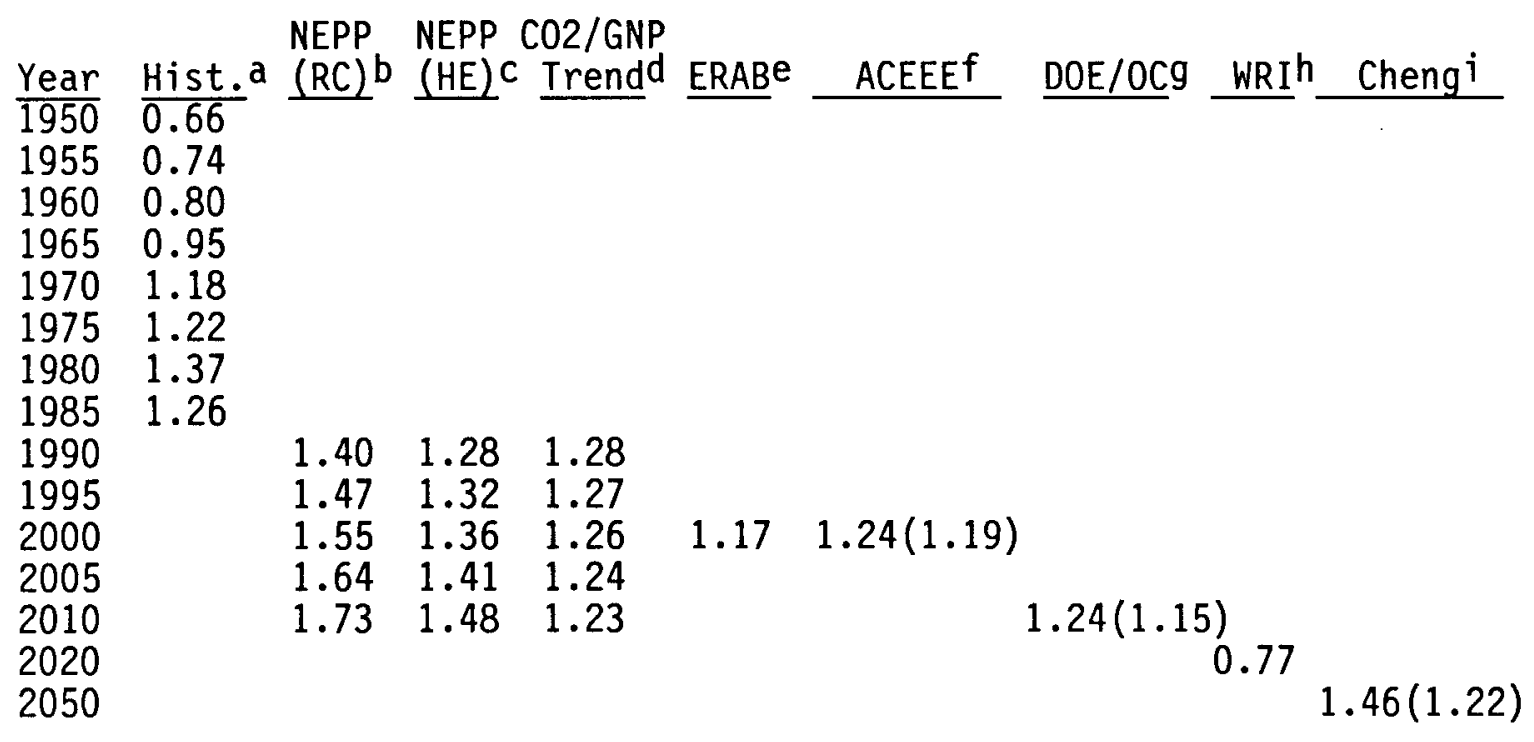

Notes:

a Historical Emissions.

b NEPP Reference Case forecast.

c NEPP High Efficiency Case.

d Extrapolation of the $2.5 \% / y r$ rate of reduction of $\mathrm{CO}_{2} / \mathrm{GNP}$ combined with NEPP Reference Case GNP forecast.

e Includes conservation potential only.

f First value refers to ACEEE forecast published in Chandler et al. (1988). Second value refers to additional $\mathrm{CO}_{2}$ emissions reductions possible by replacing some coal fired electric power with gas turbine electric power generation. Energy values provided by R.H. Williams in a personal communication.

g First value from Table 22. No account is taken of the potential for further reductions associated with electric power generation. The second value includes a calculation which increases total natural gas consumption to 20 quads and uses the increase to replace coal fired power generating capacity with advanced gas turbine technology. Gas turbines are assumed to be 0.405 efficient including transmission and distribution losses ( 0.45 efficiency at the busbar). Coal fired capacity is assumed to be 0.3 efficient including transmission and distribution losses.

$h$ WRI refers to the analysis of Goldemberg et al. (1987).

$i$ First value refers to Cheng et al. (1986) energy intensity reduction only. Second value refers to combined effect of energy intensity reduction with accelerated introduction of nuclear power. 


\section{CONTENTS}

EXECUTIVE SUMMARY $\ldots \ldots \ldots \ldots \ldots \ldots \ldots \ldots \ldots \ldots \ldots \ldots \ldots \ldots \ldots \ldots \ldots \ldots$

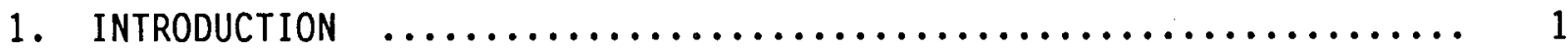

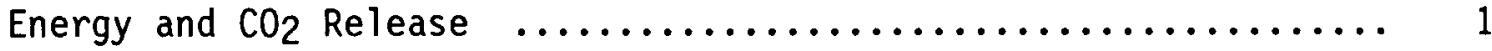

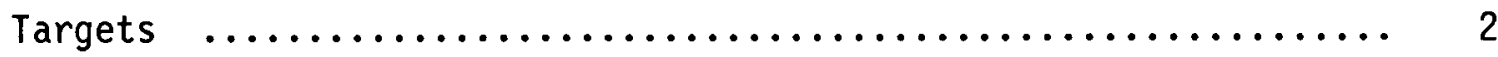

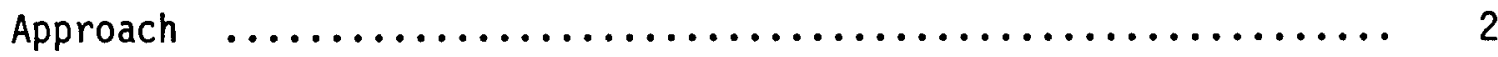

2. AGGREGATE ENERGY AND C02 EMISSIONS $1950-1985 \ldots \ldots \ldots \ldots \ldots \ldots$

3. NATURAL GAS SUBSTITUTION FOR COAL $\ldots \ldots \ldots \ldots \ldots \ldots \ldots \ldots \ldots \ldots$

Energy Supply and $\mathrm{CO}_{2}$ Emissions Targets $\ldots \ldots \ldots \ldots \ldots \ldots \ldots$

Inter-Energy Substitution Without Major Capital Stock Changes ... 14

New Electric Power Generating Technologies $\quad . . \ldots \ldots \ldots \ldots \ldots \ldots$

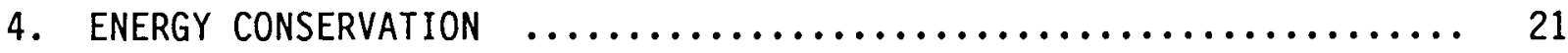

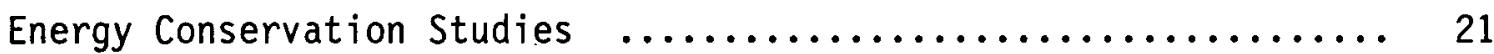

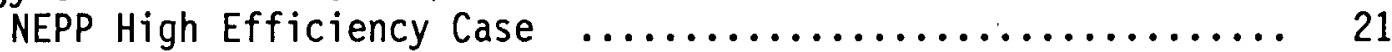

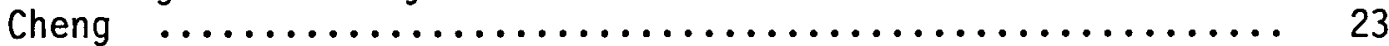

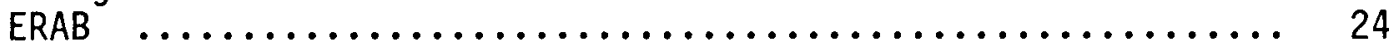

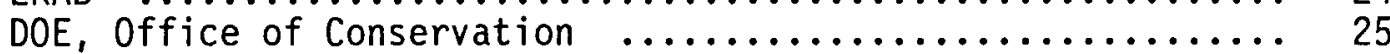

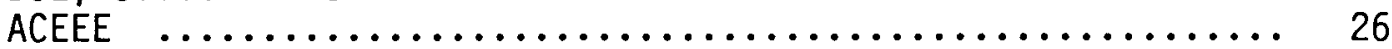

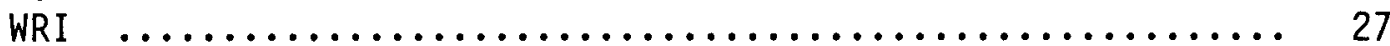

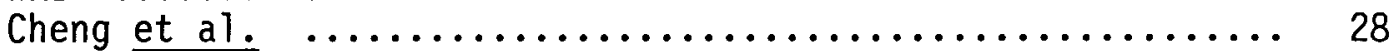

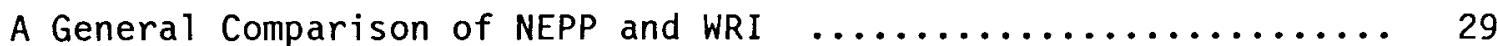

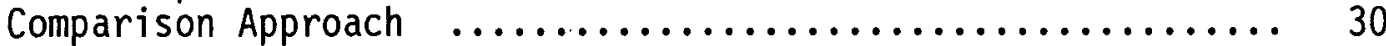

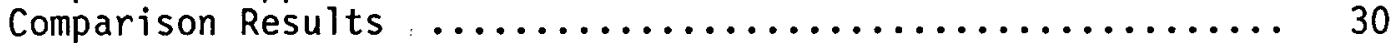

Principal Modeling Differences--Economic Structure ........ 35

Principal Modeling Differences--Technology ............ 36

Principal Modeling Differences--Consumer Discount Rates .... 36

Comparison Conclusions ....................... 37

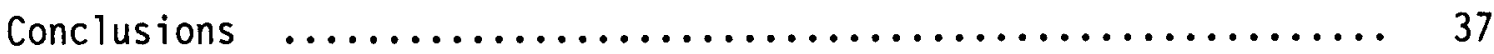

5. THE FEASIBILITY AND GLOBAL IMPACT OF REDUCING U.S. $\mathrm{CO}_{2}$ EMISSIONS $\ldots 38$

Estimates of U.S. $\mathrm{CO}_{2}$ Emissions Reduction Potential $\ldots \ldots \ldots \ldots . . .38$

The Effect of U.S. $\mathrm{CO}_{2}$ Emissions Reductions on Global Emissions .. 41 NOTES 


\section{CONTENTS}

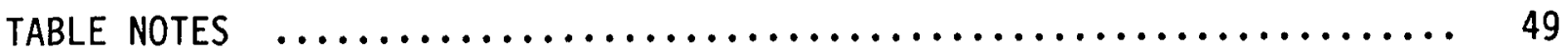

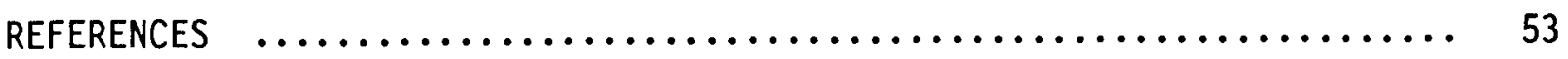

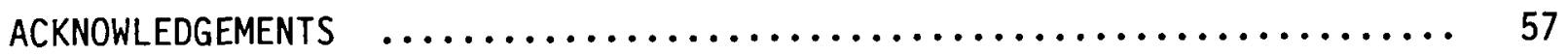

viji 


\section{INTRODUCTION}

Carbon dioxide $\left(\mathrm{CO}_{2}\right)$ is a byproduct of the combustion of fossil fuels. The United States annually (1985) burns 66x1015Btu/yr (quads/yr) of fossil fuels. This amounted to 90 percent of the 74 quads/yr of primary energy used in 1985. In comparison, global energy production was 302 quads/yr in 1985 with 266 quads/yr (88 percent) in the form of fossil fuels. The use of fossil fuels for energy released approximately $1.25 \times 1015 \mathrm{gC} / \mathrm{yr}$ (petagrams of carbon per year or $\mathrm{PgC} / \mathrm{yr}$ ) in the United States. This is approximately 25 percent of the global release of $5.2 \mathrm{PgC} / \mathrm{yr} .1$

The concentration of $\mathrm{CO}_{2}$ in the atmosphere has been growing at approximately 0.4 percent per year since 1958 with total carbon in the atmosphere reaching $720 \times 1015 \mathrm{gC}$ in 19822 . The rate of growth of $\mathrm{CO}_{2}$ emissions from fossil fuel use has been considerably faster averaging more than four percent per year between 1950 and 1979 when global emissions peaked at 5.4PgC/yr.3 Between 1980 and 1985 global emissions ceased to grow and U.S. $\mathrm{CO}_{2}$ emissions declined by almost $10 \%$ despite an increase in GNP.

Because $\mathrm{CO}_{2}$ is a greenhouse gas which allows incoming solar radiation to penetrate but absorbs infrared radiation returning to space, increases in its concentration are expected to raise the mean global surface temperature and affect other measures of the climate. Concern over the possibility of climate change due to fossil fuel burning and increased concentrations of $\mathrm{CO}_{2}$ have lead to questions about feasibility and cost of reducing the rate of emissions.

The purpose of this paper is to provide a preliminary examination of the feasibility and cost of reducing U.S. $\mathrm{CO}_{2}$ emissions rates via energy conservation and the substitution of natural gas for coal in the period to 2010. The study makes no attempt to explore specific policies that might be employed to achieve technically feasible $\mathrm{CO}_{2}$ reductions.

\section{Energy and $\mathrm{CO}_{2}$ Release:}

Emissions of $\mathrm{CO}_{2}$ occur whenever any fossil fuel is oxidized. Nevertheless, the rate of emission varies among fuels. The variation is primarily dependent on the relative abundance of carbon and hydrogen. Average emissions coefficients for oil, gas and coal are given in Table 1.

In general non-fossil fuels do not release $\mathrm{CO}_{2}$ to the atmosphere. That is, energy sources such as hydroelectric power, nuclear power (including both fission and fusion), and solar energy (including photovoltaic, heliostats, tidal, wind, OTEC and other "renewables" such as geothermal energy) do not release any $\mathrm{CO}_{2}$ to the atmosphere. Biomass energy is a special case. Biomass contains carbon, and therefore when it is burned or otherwise oxidized, releases $\mathrm{CO}_{2}$ to the atmosphere. The carbon that is released, however, was originally taken out of the atmosphere and stored in the plant during its period of growth. Biomass therefore releases no net $\mathrm{CO}_{2}$ to the atmosphere during its growth, harvest and use cycle. If the cycle is extended and land-use is changing, there can be either net additions or reductions in atmospheric $\mathrm{CO}_{2}$ by biomass. 
Table 1: Average $\mathrm{CO}_{2}$ Emissions Coefficients by Fue1

\begin{tabular}{|c|c|c|}
\hline $\begin{array}{l}\text { Fuel } \\
0 i 1 \\
\text { Gas } \\
\text { Coal } \\
\text { Shale* }\end{array}$ & $\begin{array}{l}\frac{g C / M j}{19.2} \\
13.8 \\
23.8 \\
27.9\end{array}$ & $\begin{array}{l}\mathrm{gC} / \mathrm{kBtu} \\
20.256 \\
14.4535 \\
25.109 \\
29.4345\end{array}$ \\
\hline
\end{tabular}

"Shale refers to the mining of oil shale found in carbonate rock formations.

Source: Edmonds and Reilly (1985), p.266.

Deforestation of the tropics releases $\mathrm{CO}_{2}$ tied up in the form of biomass sequestered at a much earlier date. Whenever forest regrowth is not keeping pace with deforestation, there is a net release of carbon to the atmosphere. Similarly, a growing commercial biomass industry which planted in anticipation of later harvest and energy use would require a growing biomass stock and therefore would result in net removal of carbon from the atmosphere.

\section{Targets:}

To assess the ability of the U.S. to reduce future $\mathrm{CO}_{2}$ emissions, four different potential targets have been identified, as well as two different time frames of analysis. The targets, given in Table 2, are constant emissions, and a 10,25 and 50 percent reduction of emissions from current (1985) rates.

Table 2: $\mathrm{CO}_{2}$ Emissions Constraints for Three Emissions Reduction Targets

\begin{tabular}{c}
$\mathrm{CO}_{2}$ REDUCTIION \\
TARGET \\
\hline $0 \%$ \\
$10 \%$ \\
$25 \%$ \\
$50 \%$
\end{tabular}

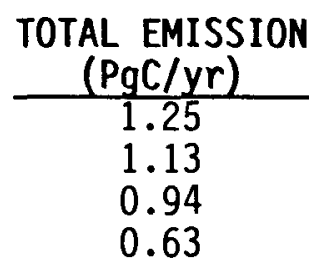

Approach:

Future U.S. $\mathrm{CO}_{2}$ emissions cannot be foreseen any better than future production and use of energy can be foreseen. The ease or difficulty of achieving the emissions targets presented in Table 2 depends, in part on the evolution of the U.S. energy system in the absence of policies whose aim is specifically to change $\mathrm{CO}_{2}$ emissions. That future is an uncertain one. Nevertheless, a reference point is needed before any analys is can begin. For the purposes of this work, future $\mathrm{CO}_{2}$ emissions are based on the energy forecast contained in the U.S. Department of Energy, National Energy Policy Plan Projections to 2010 (NEPP), (DOE, 1985). 
The NEPP was chosen because it is a well documented reference forecast of the U.S. energy system, which contains energy forecasts to the year 2010. The NEPP makes no pretense to foretelling the future, but does provide a detailed description of energy producing and consuming technologies which might evolve over the period to 2010.

Actual energy production and use for 1985 and the NEPP forecast for the years 1990 through 2010 are contained in Table 3. The associated $\mathrm{CO}_{2}$ emissions are displayed in Table 4 . Table 5 shows $\mathrm{CO}_{2}$ emissions by sector with emissions by electric utilities and synfuels producers attributed to end-use sectors.

The NEPP Reference Case forecast is one which exhibits an increasing use of energy over the period between 1985 and 2010. Energy consumption grows from 74 quads in 1985 to 104 quads in 2010. While oil and gas consumption remain relatively constant over this period, coal consumption increases dramatically. 0 il consumption is 31 quads in 1985 and 33 quads in 2010. Gas consumption is 18 quads in 1985 and 18 quads in 2010. Coal consumption is 17 quads in 1985 and 36 quads in 2010. This rapid growth in coal consumption has significant implications for $\mathrm{CO}_{2}$ emissions, which grow from $1.25 \mathrm{PgC} / \mathrm{yr}$ in 1985 to $1.73 \mathrm{PgC} / \mathrm{yr}$ in 2010. This $38 \%$ increase is a major increase in the rate of loading of carbon to the atmosphere and a reversal of the 1975 to 1985 experience. Still the rate, 1.3\%/year, is slower than during most of the post World War II period, with its average annual growth rate of $2 \% / y r$.

In 1985 the transportation and electric power generating sectors accounted for approximately two-thirds of all U.S. fossil fuel $\mathrm{CO}_{2}$ emissions. This is also true of the NEPP forecast in 2010. The relative importance of the transport and electricity sectors changes, with transportation's share of total emissions declining form $32 \%$ to $25 \%$ over the forecast and electric utilities' share increasing from 35 to $45 \%$. Utilities are the source of almost half of all $\mathrm{CO}_{2}$ emissions in the year 2010 forecast.

There are five ways in which the rate of $\mathrm{CO}_{2}$ emissions could be reduced:

1. Pre-scrubbing: Carbon could be removed from fuels prior to combustion. Only the hydrogen would be burned.

2. Energy Efficiency Improvements: The amount of energy required per unit of energy service could be reduced by the use of improved energy technologies. This is one component of energy conservation.

3. Fuel Substitution: Non-fossil energy resources (nuclear, renewables, etc.) in general do not release $\mathrm{CO}_{2}$ to the atmosphere. Emissions also vary among fossil fuels.

4. Structural Change: $\mathrm{CO}_{2}$ emissions intensities vary among final products and changing the composition of final consumption, as for example from manufacture to services, can have a significant impact on energy intensity and total $\mathrm{CO}_{2}$ emissions.

5. Scrubbing: Scrubbing $\mathrm{CO}_{2}$ from the emissions stream after combustion. 
Table 3: U.S. Energy Use by Fuel and Sector: 1985 through 2010 (x1015Btu/yr)

$\underline{1985}$

Residential \& Commercial

Industrial

(Non-Energy Uses)

Transportation

Electric Utilities

Synfuels

Venting \& Flaring

Total

Total (exc. Wood)
0 il Gas Coal Electric Renewable

$2.57 \quad 7.09$

$7.70 \quad 7.10$

$3.46 \quad 0.54$

19.56

1.09

0.00

0.52

3.14

0.00

$0.00 \quad 0.09$

0.20

2.74

0.05

0.00

14.54

0.00

0.00

\subsection{8}

2.81

0.00

0.29

$-7.88$

0.00

0.00

$\begin{array}{lll}30.92 & 17.85 & 17.48\end{array}$

$\begin{array}{lll}30.92 & 17.85 & 17.48\end{array}$
0.00

0.00
1.68

0.95

0.00

0.00

7.71

0.00

0.00

10.34

7.71
Total

Total Fossil

$16.32 \quad 9.86$

$21.30 \quad 17.54$

$4.05 \quad 4.05$

$20.37 \quad 20.08$

$26.48 \quad 18.77$

$0.00 \quad 0.00$

$0.09 \quad 0.09$

$\underline{1990}$

Residential

Commercial

Industrial

(Non-Energy Uses)

Transportation

Electric Utilities

Synfuels

Venting \& Flaring

Total

Total (exc. Wood)

$\underline{1995}$

Residential

Commercial

Industrial

(Non-Energy Uses)

Transportation

Electric Utilities

Synfuels

Venting \& Flaring

Total

Total (exc. Wood)

\section{0i1 Nuclear \&}

$\frac{0 i 1}{1.8} \quad \frac{\text { Gas }}{4.5}$

$1.4 \quad 3.0$

$10.5 \quad 8.7$

$4.0 \quad 0.9$

18.5

0.6

1.4

2.9

$-0.2$

$0.0 \quad 0.1$

$\frac{\text { Coal }}{0.1}$

3.0

$0.1 \quad 2.6$

$3.6 \quad 3.5$

0.1

0.0

0.0

0.0

17.1

$-9.1$

0.1

0.0

0.0

$\begin{array}{lll}33.7 & 19.5 & 21.0\end{array}$

0.0

0.0

13.0

9.6

76.59
73.96

66.25

$\begin{array}{lll}33.7 & 19.5 & 21.0\end{array}$
1.4

0.1

1.8

0.0

0.1

9.6

0.0

0.0
Total

$\frac{\text { Total }}{10.8} \frac{\text { Foss il }}{6.4}$

$\begin{array}{ll}7.2 & 4.5\end{array}$

$28.1 \quad 22.8$

$5.0 \quad 5.0$

19.219 .1

$31.0 \quad 21.4$

$0.0 \quad 0.0$

0.10 .1

$87.2 \quad 74.2$

$83.8 \quad 74.2$
Nuclear \&

$\frac{0 i 1}{1.7} \quad$ Gas $\quad$ Coal Electric

$1.4 \quad 3.1$

10.6

4.3

18.6

1.4

0.0

0.0

$$
9.3
$$

0.1

3.0

4.1

0.1

0.0

0.0

0.0

$\begin{array}{ll}19.7 & -10.3\end{array}$

0.20 .0

0.0

0.0

-0.1
0.1

$\begin{array}{lll}33.7 & 20.4 & 23.6\end{array}$

0.2

0.2

15.1

11.0

Total

$\frac{\text { Renewable }}{1.5} \frac{\text { Total }}{11.2} \frac{\text { Fossil }}{6.3}$

0.2

2.2

$\begin{array}{ll}7.8 & 4.6\end{array}$

$29.7 \quad 23.4$

$5.3 \quad 5.3$

$\begin{array}{lll}0.2 & 19.4 & 19.2\end{array}$

11.0

0.0

0.0

$35.1 \quad 24.1$

0.10 .1

0.10 .1

$88.9 \quad 77.7$ 
2000

Residential

Commercial

Industrial

(Non-Energy Uses)

Transportation

Electric Utilities

Synfuels

Venting \& Flaring

Total

Total (exc. Wood) $\frac{0 i}{1.6}$

1.4

10.1

4.4

19.8

1.3

$-0.1$

0.0

34.1

34.1
Nuclear \&

$\frac{\text { Coal }}{0.1} \frac{\text { Electric }}{3.7} \frac{\text { Renewable Total }}{1.5} \frac{\text { Foss il }}{11.2}$

$0.1 \quad 3.3$

$3.7 \quad 4.7$

0.4

2.6

0.0

0.3

$0.0 \quad 0.0$

$22.6-11.5$

0.4

0.0

12.4

0.0

0.0

17.2

0.2

12.4

98.5

93.7
8.4

30.4

5.5

20.7

39.1

0.2

0.1
4.7

23.1

5.5

20.4

26.7

0.2

0.1
81.1

81.1

2005

Residential

Commercial

Industrial

(Non-Energy Uses)

Transportation

Electric Utilities

Synfuels

Venting \& Flaring

Total

Total (exc. Wood)

$\frac{0 i 1}{1.4} \quad \frac{\text { Gas }}{4.1}$

$1.4 \quad 3.2$

$9.8 \quad 9.3$

4.7

20.2

1.0

$-0.4$

0.1

1.0

0.6

2.2

$-0.1$

33.4

33.4
Nuclear \&

$\frac{\text { Coal Electric }}{0.1} \frac{\text { Ee }}{4.0}$

$0.1 \quad 3.5$

$4.5 \quad 5.4$

0.1

0.0

0.0

26.0

0.0

0.8

$-12.8$

0.0

0.0

0.0

$19.3 \quad 31.5$

0.1

31.5

0.1

19.5

13.7

103.8

98.0

84.2

84.2
2010

Residential

Commercial

Industrial

(Non-Energy Uses)

Transportation

Electric Utilities

Synfuels

Venting \& Flaring

Total

Total (exc. Wood)

\begin{tabular}{rr}
$0 \mathrm{il}$ & Gas \\
\cline { 2 - 2 } 1.2 & 3.9 \\
1.4 & 3.3 \\
9.5 & 9.0 \\
4.9 & 1.1 \\
20.8 & 0.6 \\
0.9 & 1.8 \\
-0.6 & -0.3 \\
0.4 & 0.1
\end{tabular}

$\frac{\text { Coal }}{0.1} \frac{\text { Electric }}{4.3}$

Nuclear \&

Total

0.1

3.7

1.8

0.9

3.4

0.0

0.9

16.2

0.0

0.0

$28.9-14.3$

1.5

0.0

$0.0 \quad 0.0$

\section{$\begin{array}{llll}33.2 & 18.3 & 35.8 & -0.0\end{array}$}

33.2
23.2

16.2

Sources: 1985 from DOE/EIA (1987c). 1995 and 2010 from DOE (1985). Note that totals may not be identical to those in original sources due to independent totaling in this table. Negative numbers refer to production. Positive numbers refer to consumption. Total electric utility energy use refers to energy input only. Total energy excludes non-energy uses (a subcomponent of industry) and subtracts electric power generation. 
Table 4: U.S. C02 Emissions by Fuel and Sector: 1985 through 2010 $(\mathrm{PgC} / \mathrm{yr})$

$\underline{1985}$

\begin{tabular}{|c|c|c|c|c|c|}
\hline $\begin{array}{l}\text { Residential/Commercial } \\
\text { Industrial } \\
\text { Transportation } \\
\text { Electric Utilities } \\
\text { Synfuels } \\
\text { Venting \& Flaring }\end{array}$ & $\begin{array}{l}0 i 1 \\
0.05 \\
0.09 \\
0.40 \\
0.02 \\
0.00 \\
0.00\end{array}$ & $\begin{array}{l}\frac{\text { Gas }}{0.10} \\
0.09 \\
0.01 \\
0.05 \\
0.00 \\
0.00\end{array}$ & $\begin{array}{l}\text { Coal } \\
0.01 \\
0.07 \\
0.00 \\
0.37 \\
0.00 \\
0.00\end{array}$ & $\begin{array}{l}\text { Total } \\
0.16 \\
0.25 \\
0.40 \\
0.43 \\
0.00 \\
0.00\end{array}$ & $\begin{array}{c}\text { (Percent) } \\
13 \% \\
20 \% \\
32 \% \\
35 \% \\
0 \% \\
0 \%\end{array}$ \\
\hline Total & 0.56 & 0.25 & 0.44 & 1.25 & $100 \%$ \\
\hline
\end{tabular}

$\underline{1990}$

Residential

Commercial

Industrial

Transportation

Electric Utilities

Synfuels

Venting \& Flaring

Total $\frac{0 i 1}{0.04}$

0.03

0.13

0.37

0.03

0.00

0.00

0.60

0.27

$\frac{\text { Gas }}{0.07}$

0.04

0.11

0.01

0.04

$-0.00$

0.00

0.52

$\frac{\text { Coal }}{0.00}$

0.00

0.09

0.00

0.43

0.00

0.00

1.40

$\frac{\text { Total }}{0.10}$

$\frac{0 i 1}{0.03}$

0.03

0.13

0.38

0.03

0.00

0.00

0.60

Commercial

Industrial

Electric Utilities

Synfuels

Total $\frac{\text { Coal }}{0.00}$

\section{$\frac{\text { Gas }}{0.07}$}

0.04

0.12

0.01

0.04

$-0.00$

0.00

0.28

0.59

0.00

0.09

0.00

0.49

0.01

0.00

\begin{tabular}{l} 
Total \\
\hline 0.10 \\
0.08 \\
0.33 \\
0.39 \\
0.57 \\
0.00 \\
0.00
\end{tabular}

(Percent)

$7 \%$

5\%

23\%

$26 \%$

$39 \%$

$0 \%$

$0 \%$

0.00

1.47

$100 \%$
0.07

0.33

0.38

0.50

0.00

0.00

\begin{tabular}{c} 
(Percent) \\
\hline $7 \%$ \\
$5 \%$ \\
$24 \%$ \\
$27 \%$ \\
$36 \%$ \\
$0 \%$ \\
$0 \%$ \\
$100 \%$
\end{tabular}


$\underline{2000}$

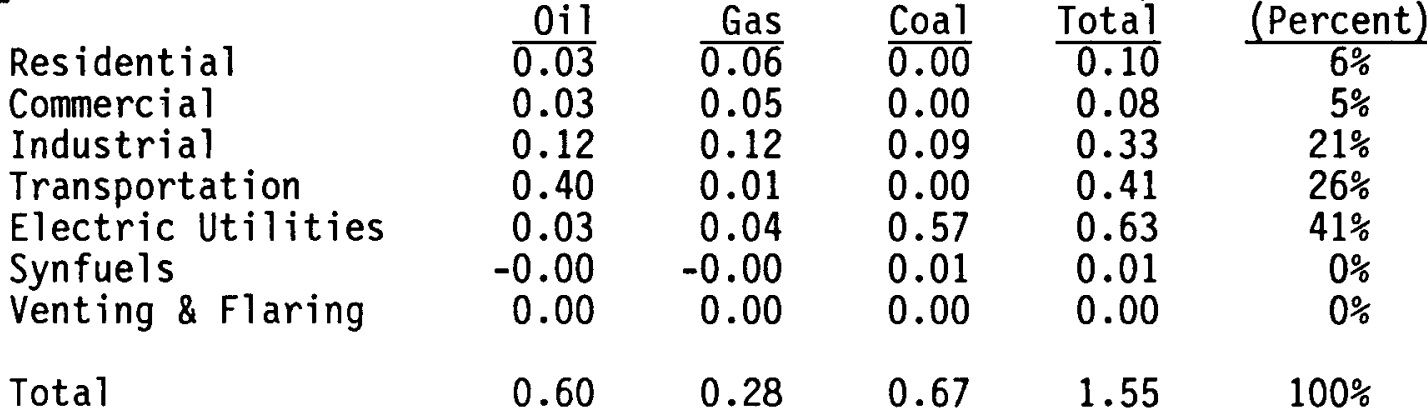

\section{$\underline{2005}$}

\begin{tabular}{lrrrrc} 
Residential & \multicolumn{1}{c}{ il } & $\frac{G a s}{}$ & Coal & Total & (Percent) \\
Commercial & 0.03 & 0.06 & 0.00 & 0.09 & $6 \%$ \\
Industrial & 0.03 & 0.05 & 0.00 & 0.08 & $5 \%$ \\
Transportation & 0.10 & 0.12 & 0.11 & 0.33 & $20 \%$ \\
Electric Utilities & 0.41 & 0.01 & 0.00 & 0.42 & $26 \%$ \\
Synfuels & 0.02 & 0.03 & 0.65 & 0.70 & $43 \%$ \\
Venting \& Flaring & -0.01 & -0.00 & 0.02 & 0.01 & $1 \%$ \\
& 0.00 & 0.00 & 0.00 & 0.00 & $0 \%$ \\
Total & 0.58 & 0.27 & 0.79 & 1.64 & $100 \%$
\end{tabular}

$\underline{2010}$

\begin{tabular}{|c|c|c|c|c|c|}
\hline $\begin{array}{l}\text { Residential } \\
\text { Commercial } \\
\text { Industrial } \\
\text { Transportation } \\
\text { Electric Utilities } \\
\text { Synfuels } \\
\text { Venting \& Flaring }\end{array}$ & $\begin{array}{r}\frac{0.11}{0.02} \\
0.03 \\
0.09 \\
0.42 \\
0.02 \\
-0.01 \\
0.01\end{array}$ & $\begin{array}{r}\frac{G a S}{0.06} \\
0.05 \\
0.11 \\
0.01 \\
0.03 \\
-0.00 \\
0.00\end{array}$ & $\begin{array}{l}\text { Coal } \\
0.00 \\
0.00 \\
0.13 \\
0.00 \\
0.73 \\
0.04 \\
0.00\end{array}$ & $\begin{array}{l}\text { Total } \\
0.08 \\
0.08 \\
0.34 \\
0.43 \\
0.77 \\
0.02 \\
0.01\end{array}$ & $\begin{array}{c}\text { Percent } \\
5 \% \\
5 \% \\
19 \% \\
25 \% \\
44 \% \\
1 \% \\
1 \%\end{array}$ \\
\hline Total & 0.58 & 0.25 & 0.90 & 1.73 & $100 \%$ \\
\hline
\end{tabular}

NOTES: Emissions coefficients are given in Table 1. Entries in the 0il column for Venting and Flaring refer to $\mathrm{CO}_{2}$ emitted from carbonate rock mining of oil shales. Negative numbers refer to emissions from synfuels. To avoid double counting of emissions the carbon associated with the energy input to the synfuel transformation appears as a positive value while the carbon content of the non-oxidized output of synfuels appears as a negative entry. Totals may not add due to independent rounding. 
Table 5: U.S. CO2 Emissions by Fuel and Sector With Electric Utility and Synfuel Emissions Attributed to End Use Sectors: 1985 through 2010

\section{$\underline{1985}$}

Residential/ Commercial

Industrial

Transportation

Total

Percent
Syn0il Gas Coal Elec Fuels Total Percent

\subsection{5}

0.09

0.40

0.10

0.10

0.01

0.07

0.26

0.15

0.01

0.00

0.02

0.00

0.00

0.00

0.42

0.40

0.42

$34 \%$

$\begin{array}{ll}0.53 & 0.21\end{array}$

0.07

$0.43 \quad 0.00$

$35 \%$
$1.25 \quad 100 \%$

$100 \%$

\section{0}

Residential

Commercial

Industrial

Transportation

Total

Percent

\begin{tabular}{|c|c|c|c|c|c|c|}
\hline $\begin{array}{r}0 i 1 \\
0.04 \\
0.03\end{array}$ & $\begin{array}{l}\text { Gas } \\
0.07 \\
0.04 \\
0.11 \\
0.01\end{array}$ & $\begin{array}{l}\text { Coal } \\
0.00 \\
0.00 \\
0.09 \\
0.00\end{array}$ & $\begin{array}{l}\text { Elec } \\
0.16 \\
0.14 \\
0.19 \\
0.00\end{array}$ & $\begin{array}{r}\text { Syn- } \\
\text { Fuels } \\
0.00 \\
0.00 \\
0.00 \\
0.00\end{array}$ & $\begin{array}{c}\text { Total } \\
0.27 \\
0.22 \\
0.53 \\
0.38\end{array}$ & $\begin{array}{c}\text { Percent } \\
19 \% \\
16 \% \\
38 \% \\
28 \%\end{array}$ \\
\hline 5 & 0.2 & & $\begin{array}{r}0.50 \\
36 \%\end{array}$ & $\begin{array}{r}0.00 \\
0 \%\end{array}$ & $\begin{array}{l}1.40 \\
100 \%\end{array}$ & $100 \%$ \\
\hline
\end{tabular}

Syn-

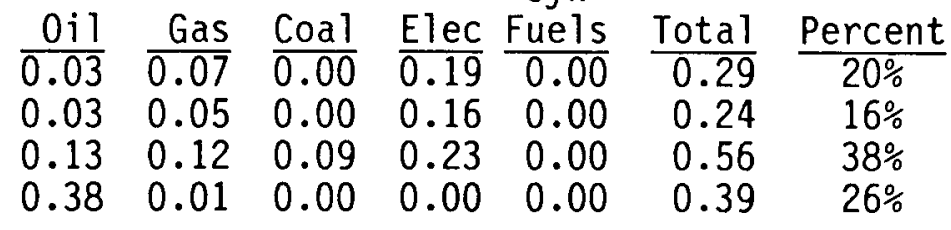

$\begin{array}{lllllll}0.57 & 0.24 & 0.09 & 0.57 & 0.00 & 1.47 & 100 \%\end{array}$ $\underline{1995}$

Residential

Commercial

Industrial

Transportation

Total

Percent

$38 \% \quad 16 \% \quad 6 \% \quad 39 \% \quad 0 \% \quad 100 \%$


$\underline{2000}$

Residential

Commercial

Industrial

Transportation

Total

Percent

2005

Residential

Commercial

Industrial

Transportation

Total

Percent

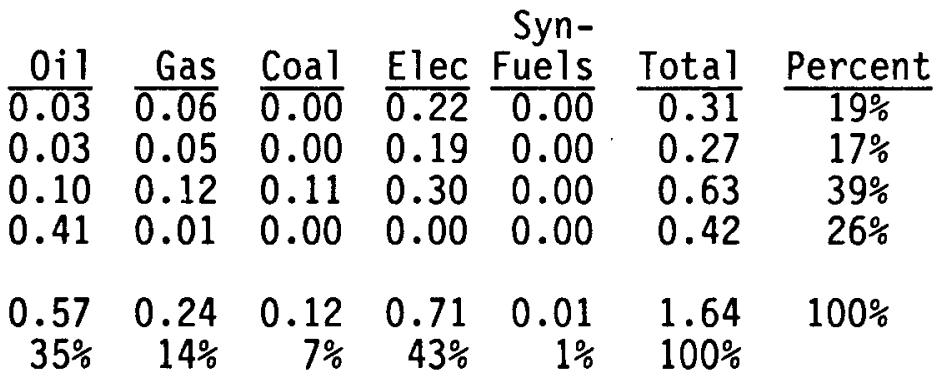

2010

Residential

Commercial

Industrial

Transportation

$\begin{array}{lll}0.58 & 0.24 & 0.10\end{array}$

$\frac{0 i 1}{0.03} \quad \frac{\text { Gas }}{0.06} \quad \frac{\text { Coal }}{0.00}$

Syn-

0.03

$0.05 \quad 0.00$

0.12

0.12

0.09

Elec Fuels

$\frac{\text { Total }}{0.30}$

Percent

0.00
0.00

0.26

$17 \%$

0.40

0.00

0.00

0.59

$38 \%$

$37 \% \quad 15 \%$

$6 \%$

0.65

0.01

1.56

$100 \%$

$41 \% \quad 0 \% \quad 100 \%$

Total

Percent

\begin{tabular}{|c|c|c|c|c|c|c|}
\hline $\begin{array}{l}\frac{011}{0.02} \\
0.03 \\
0.09 \\
0.42\end{array}$ & $\begin{array}{l}\text { Gas } \\
0.06 \\
0.05 \\
0.11 \\
0.01\end{array}$ & $\begin{array}{l}\text { Coal } \\
0.00 \\
0.00 \\
0.13 \\
0.00\end{array}$ & $\begin{array}{l}\text { Elec } \\
0.23 \\
0.20 \\
0.34 \\
0.00\end{array}$ & $\begin{array}{r}\begin{array}{r}\text { Syn- } \\
\text { Fuels }\end{array} \\
0.00 \\
0.00 \\
0.01 \\
0.01\end{array}$ & $\begin{array}{l}\text { Total } \\
0.32 \\
0.28 \\
0.68 \\
0.44\end{array}$ & $\begin{array}{c}\text { Percent } \\
18 \% \\
16 \% \\
40 \% \\
26 \%\end{array}$ \\
\hline $\begin{array}{r}0.58 \\
33 \%\end{array}$ & $\begin{array}{r}0.23 \\
13 \%\end{array}$ & $\begin{array}{r}0.13 \\
8 \%\end{array}$ & $\begin{array}{r}0.77 \\
45 \%\end{array}$ & $\begin{array}{r}0.02 \\
1 \%\end{array}$ & $\begin{array}{l}1.73 \\
100 \%\end{array}$ & $100 \%$ \\
\hline
\end{tabular}

Note: Totals do not add due to independent rounding. $\mathrm{CO}_{2}$ emissions from electric utilities, synfuels, venting and flaring and shale oil mining in carbonate rock have been apportioned to end-use sectors on the bas is of sectoral uses of oil, gas and electricity respectively. Synfuels have been distributed in proportion to combined oil and gàs usage by sector. 
In the analysis that follows, we begin by considering U.S. energy and $\mathrm{CO}_{2}$ emissions in the post World War II period. We will then proceed to examine the role of natural gas substitution for coal in the reduction of $\mathrm{CO}_{2}$ emissions in the following section and the potential of conservation to reduce $\mathrm{CO}_{2}$ emissions in Section 4. In this analys is energy conservation will include both energy efficiency improvements and structural change. We will not attempt to disaggregate their combined effects. In Section 5 we examine the joint contribution of both natural gas substitution for coal and energy conservation potential and briefly consider the impact U.S. emissions reductions might have on global emissions. We will not review the analys is of post-combustion scrubbing technologies nor pre-combustion scrubbing technologies. In the analysis that follows we will assume that neither pre- nor post-combustion carbon removal is employed.

\section{AGGREGATE ENERGY AND CO2 EMISSIONS 1950-1985:}

Between 1970 and 1985 the ratio of primary energy consumption to gross national product (E/GNP) declined at an accelerating rate. Table 6 shows the annual rate of decline over each of the five year intervals beginning in 1950 and extending through the NEPP forecast years to 2010. Little trend is perceptible before 1970. The E/GNP in 1970 was the same as it was in 1950. During the period 1970 to 1985 E/GNP declined at an average annual rate of $1.9 \% /$ year and between 1979 and 1983 the rate was $3.1 \% /$ year. The decline in E/GNP post 1970 can be seen as both a response to energy shortages and a resumption of a long-term trend that began in 1920 and extended to 1950 (Edmonds and Reilly, 1985, Ch.4). In fact, the rate of decline in E/GNP between 1920 and 1945 was $2.0 \%$ year.

Marketed energy is overwhelmingly fossil fuels. The share of fossil fuel to total energy consumption declined from 96 to $90 \%$ between 1970 and 1985. The decline is primarily the result of the rapid increase in the amount of energy provided by nuclear power. As a consequence, the ratio of fossil energy to GNP has declined at an even faster rate than E/GNP. Note that the NEPP forecast anticipates a continuation in the trend toward reduced use of fossil fuels.

Between 1950 and 1970 primary energy consumption grew at an average annual rate of $3.5 \% / y r$. This is reflected in a concomitant growth in fossil fuel $\mathrm{CO}_{2}$ emissions, which grew at an average annual rate of $3.0 \% / \mathrm{yr}$. Historical U.S. emissions are given in Table 7.

The somewhat slower growth in $\mathrm{CO}_{2}$ emissions than in energy growth is attributable largely to the shift in the composition of energy, with the share of coal declining from $39 \%$ of fossil fuel use in 1950 to $19 \%$ in 1970 . The years between 1970 and 1985 track the energy situation. $\mathrm{CO}_{2}$ emissions were approximately the same in 1985 as they were in 1975. Similarly, energy use in 1973 was the same as in 1985. In fact $\mathrm{CO}_{2}$ emissions were lower in 1985 than they were in 1980 and energy consumption declined in 1980, 1981, 1982 and 1983 as well as 1985 and 1986. 
Table 6: Relationship Between U.S. Energy Consumption and Economic Growth: 1950-1985 and NEPP Forecastsa

\begin{tabular}{|c|c|c|c|c|c|c|c|}
\hline Year & $\begin{array}{c}\text { GNP } \\
(1984 \$) \\
\end{array}$ & $\begin{array}{l}\text { Energy } \\
\text { (quads) }\end{array}$ & $\begin{array}{r}\text { Fossil } \\
\text { (quads) }\end{array}$ & $\begin{array}{c}\text { Foss il } \\
(\%)\end{array}$ & $\begin{array}{c}\text { te of } \\
E / G N P \\
(\% / y r)\end{array}$ & $\begin{array}{c}\text { nprovemen } \\
F / G N P D \\
(\% / y r)\end{array}$ & \\
\hline $\begin{array}{l}1950 \\
1955 \\
1960 \\
1965 \\
1970 \\
1975 \\
1980 \\
1985\end{array}$ & $\begin{array}{l}1341 \\
1665 \\
1855 \\
2326 \\
2692 \\
3002 \\
3550 \\
3994\end{array}$ & $\begin{array}{l}33.1 \\
38.8 \\
43.8 \\
52.7 \\
66.4 \\
70.6 \\
76.0 \\
74.0\end{array}$ & $\begin{array}{l}31.6 \\
37.4 \\
42.2 \\
50.6 \\
63.6 \\
65.3 \\
70.0 \\
66.3\end{array}$ & $\begin{array}{l}96 \\
96 \\
96 \\
96 \\
96 \\
93 \\
92 \\
90\end{array}$ & \begin{tabular}{r}
\multicolumn{1}{c}{$-\overline{1}$} \\
1.1 \\
-0.3 \\
0.8 \\
-1.7 \\
1.0 \\
1.9 \\
2.8
\end{tabular} & $\begin{array}{r}-- \\
1.0 \\
-0.2 \\
0.9 \\
-1.7 \\
1.6 \\
2.0 \\
3.4\end{array}$ & $\begin{array}{l}\text { Hist. } \\
\text { Hist. } \\
\text { Hist. } \\
\text { Hist. } \\
\text { Hist. } \\
\text { Hist. } \\
\text { Hist. } \\
\text { Hist. }\end{array}$ \\
\hline $\begin{array}{l}1990 \\
1995 \\
2000 \\
2005 \\
2010\end{array}$ & $\begin{array}{l}4623 \\
5186 \\
5825 \\
6527 \\
7320\end{array}$ & $\begin{array}{r}83.8 \\
88.9 \\
93.7 \\
98.0 \\
103.5\end{array}$ & $\begin{array}{l}74.2 \\
77.7 \\
81.1 \\
84.2 \\
87.3\end{array}$ & $\begin{array}{l}89 \\
87 \\
87 \\
86 \\
84\end{array}$ & $\begin{array}{l}0.4 \\
1.1 \\
1.3 \\
1.4 \\
1.2\end{array}$ & $\begin{array}{l}0.6 \\
1.4 \\
1.5 \\
1.5 \\
1.6\end{array}$ & $\begin{array}{l}\text { NEPP } \\
\text { NEPP } \\
\text { NEPP } \\
\text { NEPP } \\
\text { NEPP }\end{array}$ \\
\hline
\end{tabular}

Notes: a Percentage changes cannot be derived from information presented in these tables due to rounding in the values presented here. See note 9 in the end material for a description of the average annual growth rate calculation.

b F/GNP is the fossil fuel to GNP ratio.

Sources: 1950-1985 from DOE/EIA (1987c). 1995-2010 from DOE (1985).

Table 7: Historical U.S. Fossil Fuel Use and $\mathrm{CO}_{2}$ Emissions 1950-1985

\begin{tabular}{|c|c|c|c|c|c|c|c|c|c|}
\hline & & & & Total & Venting & & nerg & Jses & \\
\hline Year & $0 i 1$ & Gas & Coal & Fossil & \& Flrng & $0 i 1$ & Gas & $\overline{\text { Coal }}$ & $\mathrm{CO}_{2}$ \\
\hline$\overline{195}$ & $\overline{13.32}$ & 5.97 & $\overline{12.35}$ & 31.64 & 0.80 & $\overline{0.89}$ & $\overline{0.19}$ & $\overline{0.08}$ & 0.66 \\
\hline & & 9.00 & 11.17 & 37. & 0.77 & 1.15 & 0.28 & 0.0 & 0. \\
\hline & 19. & 12.39 & & 42. & 0.56 & 1.33 & 0.39 & 0.06 & \\
\hline & 23 & 15.77 & 11.5 & & 0 . & 1.55 & 0.50 & 0.08 & \\
\hline & & 21.7 & 12. & & & 1.97 & 0. & 0.0 & \\
\hline & & 19.9 & 12.6 & & & 2.15 & & & \\
\hline & & 20 & & & & 3. & & & \\
\hline & & 17. & 17 & & & 2. & 0 . & 0.05 & \\
\hline
\end{tabular}

UNITS: A1l energy units are in (x1015 Btu/yr or quads). $\mathrm{CO}_{2}$ emissions are denominated in $(x 1015 \mathrm{gC} / \mathrm{yr}$ or $\mathrm{PgC} / \mathrm{yr})$.

See Table Notes, p.51. 
A crude disaggregation of the composition of changes in $\mathrm{CO}_{2}$ emissions can be developed by examining the percentage changes in three elements, the ratio of $\mathrm{CO}_{2}$ emissions to energy, the ratio of energy to GNP, and the GNP. Changes in the ratio of $\mathrm{CO}_{2}$ emissions to energy reflect the effects of changes in the composition of energy supply. Changes in the ratio of energy to GNP on the other hand reflect changes in energy intensity. Changes in GNP reflect changes in the scale of activity. The percentage change in $\mathrm{CO}_{2}$ emissions is approximately equal to the sum of the percentage change in each of these three components. 4 These percentage changes are given in Table 8.

Table 8: Percentage Changes in $\mathrm{CO}_{2}$ Emissions and Three Key Components at Five Year Intervals

1955 through 1985

\begin{tabular}{|c|c|c|c|c|}
\hline $\begin{array}{l}\text { Year } \\
1955 \\
1960 \\
1965 \\
1970 \\
1975 \\
1980 \\
1985\end{array}$ & $\begin{array}{r}C 02 / E \\
-3.5 \% \\
-4.0 \% \\
-1.3 \% \\
-2.2 \% \\
-2.6 \% \\
4.2 \% \\
-5.2 \%\end{array}$ & $\begin{array}{r}\text { E/GNP } \\
-5.5 \% \\
1.3 \% \\
-4.1 \% \\
9.0 \% \\
-4.8 \% \\
-9.0 \% \\
-13.4 \%\end{array}$ & $\begin{array}{l}\text { GNP } \\
24.2 \% \\
11.4 \% \\
25.4 \% \\
15.7 \% \\
11.5 \% \\
18.3 \% \\
12.5 \%\end{array}$ & $\begin{array}{r}\mathrm{CO} 2 \\
13.3 \% \\
8.3 \% \\
18.7 \% \\
23.3 \% \\
3.4 \% \\
12.2 \% \\
-7.7 \%\end{array}$ \\
\hline
\end{tabular}

NOTES: Percentage changes refer to changes over a five year period beginning five years prior to the date indicated in this table. The sum of values in the first three rows do not sum to the value in the fourth row due to the discrete nature of the calculation. Percentage changes cannot be derived from information presented in tables 7 and 8 due to rounding. See note 9 in the end material for a description of the average annual growth rate calculation.

It is worth noting that the period 1980 to 1985 , in which $\mathrm{CO}_{2}$ emissions decline by $7.7 \%$ can be decomposed into two declining components, shifts in energy supply which contributed approximately $5 \%$ and energy conservation which contributed approximately $13 \%$, and the scale effect of the increasing GNP which tended to increase $\mathrm{CO}_{2}$ emissions by $12 \%$. During this period it appears that energy conservation contributed more than twice as much to the decline in $\mathrm{CO}_{2}$ emissions as the changing composition of energy supply.

The historical record can be looked upon as offering evidence regarding either an upper or lower bound on potential $\mathrm{CO}_{2}$ emissions. The 1970-1985 experience demonstrates that over the period of approximately five years, a pattern of energy use and $\mathrm{CO}_{2}$ emission can be reversed and that for a decade energy use and $\mathrm{CO}_{2}$ emissions rates can be held constant and in fact declined by almost $10 \%$ in the final five years.

The 1970-85 period can also be viewed as showing that the cumulative effect of energy price increases and societal responses to energy scarcity 
were insufficient in aggregate to reduce $\mathrm{CO}_{2}$ emissions significantly. Reductions in $\mathrm{CO}_{2}$ emissions in the period to 2010 via energy conservation requires energy intensity improvements at sustained rates beyond those experienced between 1975 and 1985.

\section{NATURAL GAS SUBSTITUTION FOR COAL}

\section{Energy Supply and $\mathrm{CO}_{2}$ Emissions Targets:}

The reduction of U.S. $\mathrm{CO}_{2}$ emissions from 1985 levels requires future reductions of fossil fuel consumption from 1985 levels unless Cu2 removal technologies are developed and applied widely.5 The pattern of U.S. energy supply and demand would have to be substantially restructured from that foreseen by NEPP to achieve $\mathrm{CO}_{2}$ emissions reduction targets. The NEPP forecast anticipates an increase in the rate of emission between 1985 and 2010 . Reducing emissions requires a reversal of that anticipated trend. The NEPP forecast for expanded coal use is incompatible with the $\mathrm{CO}_{2}$ emissions targets unless some form of $\mathrm{CO}_{2}$ removal technology is applied extensively. The NEPP forecast of coal consumption alone in 2010 is sufficient to make the achievement of a $50 \%$ reduction in emissions impossible without employing carbon scrubbing technologies. All oil consumption must be eliminated to meet the $10 \%$ emissions reduction target with the NEPP coal and gas consumption forecasts for the year 2010 .

To achieve any of the emissions reductions targets without carbon removal, implies that either through increased efficiency or through the substitution of non- $\mathrm{CO}_{2}$ emitting energy supply technologies, fossil fuel consumption must decline.

The implications for domestic oil and gas production are not as great as for domestic coal production. Domestic oil production is expected to remain below domestic consumption. In the future domestic oil production is anticipated to decline and oil imports are anticipated to grow in the NEPP forecast. $\mathrm{CO}_{2}$ emissions associated with U.S. production are anticipated to decline from $0.43 \mathrm{PgC} / \mathrm{yr}$ in 1985 to $0.32 \mathrm{PgC} / \mathrm{yr}$ in 2010. The impact of $\mathrm{CO}_{2}$ emissions reductions targets on domestic oil production should therefore not be large.

In general the lower rate of $\mathrm{CO}_{2}$ emission per unit of energy consumption makes natural gas a supply option which could be expanded. The effect of $\mathrm{CO}_{2}$ emissions reduction targets on natural gas is discussed below in some detail.

Coal production is another matter. Its emissions coefficient is highest among the fossil fuels and is even higher when used to produce synthetic fuels (Marland, 1983). The NEPP forecast anticipates a doubling of both U.S. coal production and consumption. The reduction of U.S. $\mathrm{CO}_{2}$ emissions would require a substantial reduction in the anticipated domestic market for coal. Coal was the fifth largest U.S. export in 1982 (ERAB, 1988). A strategy designed to reduce $\mathrm{CO}_{2}$ emissions would also raise the prospect of controls on the export of coal as well. U.S. $\mathrm{CO}_{2}$ emissions reduction targets of 10,25 or $50 \%$ could have profound effects on the prospects for future U.S. coal production. 
Inter-Energy Substitution Without Major Capital Stock Changes:

Very little time remains before the year 1995 (approximately 6 years). Fuel substitution options over this period are limited. Natural gas substitution for other fossil fuels has been suggested. The logic of this proposition is simple. Natural gas emits half the $\mathrm{CO}_{2}$ per unit of energy as coal (Table 1) and natural gas substitutes directly and at low cost for oil and coal in many applications. The ability of natural gas substitution for other fossil fuels can only partially reduce $\mathrm{CO}_{2}$ emissions. There are two reasons.

First, while natural gas releases less $\mathrm{C}_{2}$ per unit energy than either coal or oil, natural gas still releases some $\mathrm{CO}_{2}$. Even if all 77.7 quads of fossil fuel consumption in the year 1995 NEPP forecast and 87.3 in the year 2010 NEPP forecast were in the form of natural gas, emissions would achieve the $10 \%$ reduction target in 1995 , but would return to 1985 levels by the year $2010(1.26 \mathrm{PgC} / \mathrm{yr})$.

Second, future natural gas prices may increase although recent DOE analys is (DOE, 1988) suggests much larger supplies of natural gas are available at reasonable prices than were previously forecasted. It may be impossible for the direct substitution of conventional natural gas for coal in electric utility boilers to provide more than a marginal contribution (less than 0.08 $\mathrm{PgC} / \mathrm{yr}$ ) toward even the $10 \%$ emissions reduction target unless natural gas prices rise sufficiently to induce the needed supplies. It is clear that the price of gas will increase over the long run as the resource base is consumed. Eventually, high prices will drive consumers to prefer less expensive substitutes which may be available. Current natural gas production and delivery capacity is limited to less than 25 trillion cubic feet (tcf) per year. Higher gas prices would be required to coax out the investments needed to raise capacity, but higher prices would also discourage higher gas consumption.

An estimate of $\mathrm{CO}_{2}$ emissions reductions that could be obtained by direct firing of natural gas in electric utility coal boilers was obtained by assuming that natural gas availability was increased to 25 tcf per year starting in 1985. The incremental addition to natural gas availability over the NEPP forecast (5 quads/yr in 1995 and 7 quads/yr in 2010) was assigned to replace coal in utility boilers. It was assumed that the natural gas substituted perfectly for coal and that there were no significant increases in capital requirements. For example, it was assumed that the heat rates for natural gas and coal were approximately equal and that no new natural gas pipelines needed to be built.6 Fuel costs for coal and gas were taken from NEPP forecasts of industrial fuel prices.

Annual $\mathrm{CO}_{2}$ emissions were reduced by $0.053 \mathrm{PgC} / \mathrm{yr}$ in 1995 and by $0.075 \mathrm{PgC} / \mathrm{yr}$ in 2010 . The cost of these reductions was calculated to be $\$ 15 \times 109$ in 1995 and $\$ 48 \times 109$ in 2010 (Table 9). 
Table 9: U.S. $\mathrm{CO}_{2}$ Emissions Reductions and Associated Costs

With Direct Use of Natural Gas in Coal Boilers: 1995 and 2010

\begin{tabular}{|c|c|c|c|}
\hline Year & $\begin{array}{l}\text { Natural Gas } \\
\text { Substituted } \\
\text { for Coal } \\
(x 1015 \mathrm{Btu} / \mathrm{yr})\end{array}$ & $\begin{array}{l}\mathrm{CO}_{2} \text { Emissions } \\
\text { Reduction } \\
\text { (PgC/yr) }\end{array}$ & $\begin{array}{l}\text { Total Cost } \\
(\times 1091984 \$\end{array}$ \\
\hline $\begin{array}{l}1995 \\
2010\end{array}$ & $\begin{array}{l}5 \\
7 \\
\end{array}$ & $\begin{array}{l}0.053 \\
0.075\end{array}$ & $\begin{array}{l}15 \\
48\end{array}$ \\
\hline
\end{tabular}

NOTES: The rate of $\mathrm{CO}_{2}$ emissions reduction per Btu gas substituted for coal is calculated as 0.025109 (coal) -0.0144535 (gas) $=0.0106555 \mathrm{gC} /$ Btu.

NEPP energy prices are given below:
NEPP Industrial Sector Fuel Prices
1995 and 2010
(1984\$/mBtu)

$\begin{array}{lll}\text { Gas } & \frac{1995}{4.99} & \frac{2010}{9.23} \\ \text { Coal } & 2.00 & 2.36\end{array}$

New Electric Power Generating Technologies:

New electric power generating technologies show promise of providing short term improvements in the rate of $\mathrm{CO}_{2}$ emissions per unit of electrical energy generated. Fossil fuel electric power currently (1985) averages 0.0549 gC/Btue energy produced. The average fossil fuel power plant was producing electricity at a heat rate of $10339 \mathrm{Btu} / \mathrm{kWh}_{\mathrm{e}}$ in 1985 and an implied efficiency of 0.33 .7 New technologies, with substantially improved efficiencies of electricity production, currently in various stages of development and demonstration, are expected to become available in the near future. These include the combined cycle and advanced combined cycle gas turbines, the steaminjected gas turbine (STIG), and the intercooled STIG (ISTIG) (Table 10). New PURPA regulations have already lead to the introduction of some new gas turbine technologies by qualifying facilities.

Performance and cost characteristics of various new technologies have been estimated by Williams and Larson (1988). Their estimates are reproduced in Table 11. Of particular note are the $40 \%$ and higher efficiencies for all of the natural gas-fired gas turbine systems. Even when combined with gasifiers to use coal, system efficiencies remain above $33 \%$ and ISTIG unit efficiencies are $42 \%$. Unit sizes of the gas turbine technologies are small by comparison to conventional coal and nuclear units. 
Table 10: New Gas Turbine Technologies

Technology

,

Current

Combined Cycle

Gas Turbine

(Cur.CC)

Advanced

Combined Cycle

Gas Turbine

(Adv.CC)

Description

Status

This technology combines a

gas turbine with a steam

turbine. In the gas turbine

hot fuel combustion produces

electricity directly. In

addition, high temperature

turbine exhaust is used to

raise steam in a heat recovery steam generator (HRSG).On line. 4.6 GW U.S. generating capacity in 1985

Same as above except that advanced materials technology is applied, for example to increase inlet temperature.

Commercial.

First order placed

by VEPCO for a 135

MW GE Frame $7 F$ gas

turbine plus a 70

MW steam turbine.

Steam Injected Gas Turbine (STIG)

An aeroderivative turbine in which high pressure steam is recovered from a HRSG. The recovered steam is injected into the combustor, heated to the turbine inlet temperature, Six 50 MWe units based on the Detroit Diesel Allison 501-KH have been installed and two and expanded in the turbine.

Intercooled Steam Injected Gas Turbine (ISTIG)

Same as above except that intercooling is used between the two compressor stages. more are on order.

Technology exists but has not yet been deployed.

SOURCE: Williams and Larson (1988), personal communication with R.H. Williams, 12 August 1988, Moore (1988). 
The cost of a natural gas turbine strategy looks attractive in the near term. That is, the natural gas-fired gas turbine systems have lower levelized busbar costs (Table 11) than conventional coal fired power plants at current natural gas prices. By the year 1995 NEPP forecast natural gas prices have risen $22 \%$ and by 2010 they rise 125\%. At those prices these technologies have lost their competitive advantage.

Even with greatly increased generating efficiencies, the demand for natural gas in the year 2010 required to meet the incremental increase in electric power demand over 1985 levels is 10 to 11 quads, Table 12. Such an increase in the demand for natural gas would likely drive the price of natural gas higher unless overall demand for natural gas was lowered by conservation in other sectors.

We have examined the degree to which these energy supply technologies could, by themselves, reduce U.S. $\mathrm{CO}_{2}$ emissions. To explore this potential, we have constructed a case in which total NEPP energy and electricity demand are assumed to be realized, but all new fossil fuel electric power generation over 1985 levels comes from ISTIG units or units with the same efficiency. The effect of introducing high efficiency gas turbine technologies into the base electric power network were calculated and are displayed in Table 12. Post 1985 additional fossil fuel electric power amounts to 1.6 quads in 1995 and 4.3 quads in 2010. The ISTIG unit is assumed to have $47 \%$ efficiencies of power generation. This number is uncertain. As indicated in Table 10, there are no operating units currently on line or in demonstration. Actual performance certainly will differ from the estimated performance.

We note that the introduction of new natural gas-fired turbine technology will have a significant effect on the emission of $\mathrm{CO}_{2}$ if this technology is substituted for current steam coal technologies. Table 12 indicates that $\mathrm{CO}_{2}$ emissions could be reduced by up to $0.2 \mathrm{PgC} / \mathrm{yr}$. This reduction is the result of both significantly improved efficiencies available with new gas turbines (42 to $47 \%$ ) as compared to coal (34.6\%), and the lower emission coefficient for natural gas $(14.5 \mathrm{gC} / \mathrm{kBtu})$ as compared with coal $(25.1 \mathrm{gC} / \mathrm{kBtu})$. The addition of an integrated gasification unit to the system nullifies much of the $\mathrm{CO}_{2}$ emissions reduction. Utilities produce only marginally less $\mathrm{CO}_{2}$ by selecting turbine technologies which employ coal gasification or pressurized fluidized bed combustion units than by simply generating power from a current state of the technology steam coal unit. This result means that the increase in efficiency from $34.6 \%$ to $42 \%$ alone is not enough to reduce significantly expected emissions.

We also note that these technologies are insufficient in and of themselves to allow the achievement of any of the $\mathrm{CO}_{2}$ emissions reduction targets. 
Table 11: Cost/Performance Characteristics for U.S. Central Station Power Plantsa

STEAM-ELECTRIC PLANTS

Typ

Unit Size (MW)

Efficiency $(\%)$ e

Unit cost $(\$ / \mathrm{kW})$

\begin{tabular}{lrr} 
& \multicolumn{3}{c}{ Coa1b,c } \\
\hline $2 \times 500$ & 500 & 200 \\
34.6 & 34.6 & 34.6 \\
1300 & 1360 & 1820
\end{tabular}

Levelized Busbar Cost (cents/kWh)

$\begin{array}{llll}\text { Capitalf } & 1.56 & 1.63 & 2.18 \\ \text { Fuel } & 1.80 & 1.80 & 1.80 \\ \text { O\&M } & \frac{0.85}{4.21} & \frac{0.95}{4.38} & \frac{1.31}{5.29}\end{array}$

\begin{tabular}{cc}
\multicolumn{2}{c}{ Light Water Reactord } \\
\hline Current & Targeted \\
\hline 1100 & 1100 \\
33.4 & 33.4 \\
2960 & 1610
\end{tabular}

3.54

0.87

$\frac{1.06}{5.47}$

1.93

0.87

$\frac{1.06}{3.86}$

NATURAL GAS-FIRED GAS TURBINE SYSTEMS $g$

TIT (OF)

Unit Size (MW)

Efficiency $(\%)$ e

Unit Cost $(\$ / \mathrm{kW})$
1986 Natural Gas Priceh Cur.CC Adv.CC $\frac{\text { STIG ISTIG }}{2200}$ $\frac{000}{2000} \frac{\text { Advec }}{2300} \frac{S 1 G}{2200} \frac{1 S 11 G}{2500}$ $236 \quad 205$ $41.9 \quad 45.0$

$490 \quad 490$ $4 \times 51$

40.0 410
110

47.0 410
2X 1986 Natural Gas Price Cur.CC Adv.CC STIG ISTIG $2000 \frac{100}{2300} \quad \frac{5100}{2500}$ $\begin{array}{llll}2 \times 118 & 205 & 4 \times 51 & 110\end{array}$ $\begin{array}{rrrr}41.9 & 42.3 & 40.0 & 47.0\end{array}$ $\begin{array}{llll}490 & 490 & 410 & 410\end{array}$

Levelized Busbar Cost (cents/kWh)

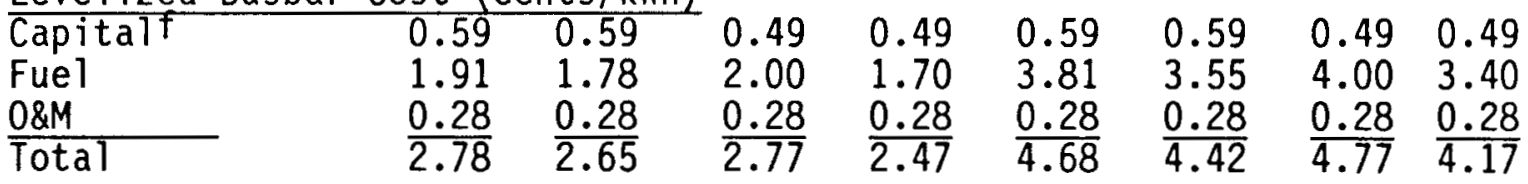

ALTERNATIVE COAL-GAS-FIRED GAS TURBINE SYSTEMS $c, i$

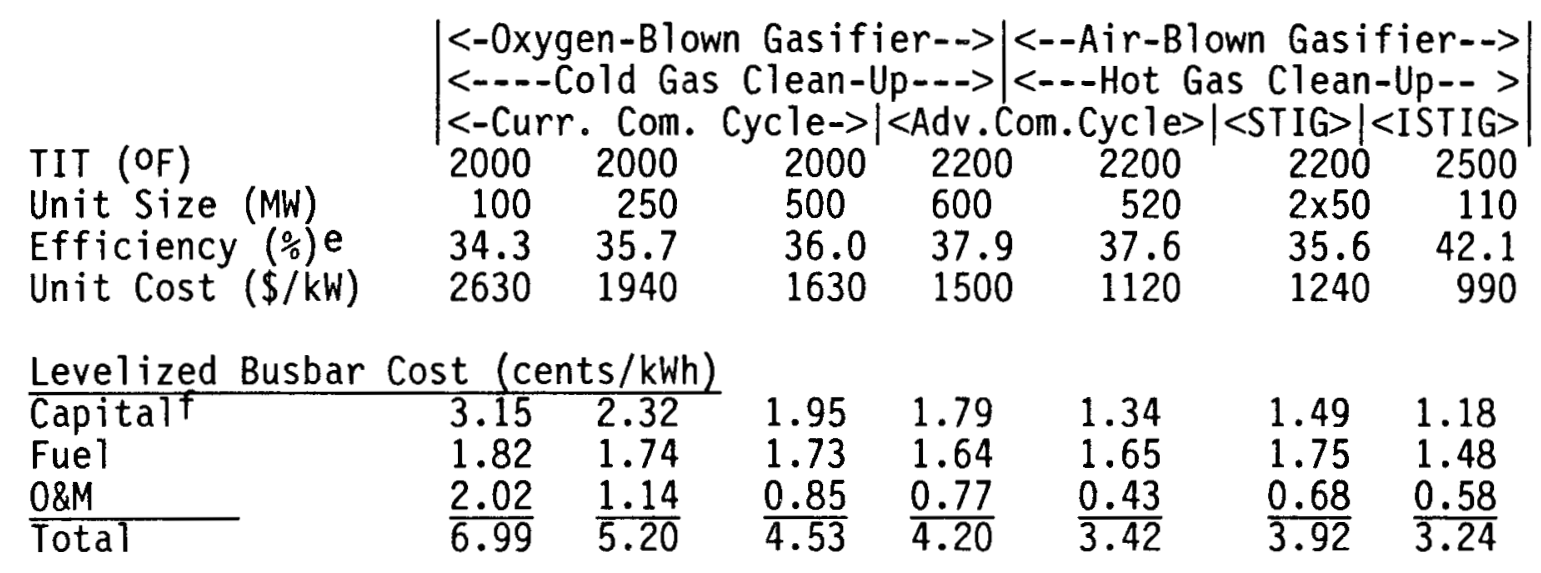

See Table Notes, page 51-2. 
Table 12: U.S. $\mathrm{CO}_{2}$ Emissions Associated With Incremental

Fossil Fuel Electric Power Generating Capacity Additions

Of 1.6 and 4.3 quads/yr in 1995 and 2010 Respectively

By Alternative Technologies a

Technology

Conventional Coal b

ISTIG

Curr. Comb. Cycle

Coal Gas + ISTIG

Coal Gas + Cur.CC

Pressur. Fluid. Bed
Fuel Reguirement (x1015 Btu/yr)

$\frac{1995}{5.14} \frac{2010}{13.81}$

3.78

10.17

4.23

11.38

4.23

4.94

4.44
11.38

13.27

11.94
$\mathrm{CO}_{2}$ Emissions

(x1015 gC/yr)

$\frac{1995}{0.13} \quad \frac{2010}{0.35}$

0.05

0.06

0.11

0.12

0.11
Net Reduction in $\mathrm{CO}_{2}$ Emissions Compared With Conventional Coal

\begin{tabular}{|c|c|}
\hline \multirow{2}{*}{\multicolumn{2}{|c|}{$(x 1015 \mathrm{gC} / \mathrm{yr})$}} \\
\hline & \\
\hline & \\
\hline
\end{tabular}

NOTES:

a Efficiencies for all technologies except the pressurized fluidized bed combustion unit are taken from Table 11 are as follows:

Conventional Coal, 34.6\%; ISTIG, 47\%; Current Combined Cycle, 42\%; ISTIG with hot gas clean-up and air blown coal gasifier, $42 \%$; and a $500 \mathrm{MW}$ Current Combined Cycle unit with cold gas clean-up and an oxygen-blown coal gasifier, $36 \%$. The pressurized fluidized bed combustion unit is assumed to achieve $40 \%$ efficiency. Efficiencies are assumed to be for an integrated system. Transmission losses are assumed to be $10 \%$. Efficiencies used in this table are not consistent with those used in the NEPP forecast. The average coal fired electric power plant in NEPP has an efficiency of approximately $33 \%$ rather than the $34.6 \%$ used in these calculations. The higher efficiency was used here to maintain consistency with the technologies specified in Table 11.

b SOx removal via stack gas scrubbing will actually add an additional 1 to $2 \%$ to $\mathrm{CO}_{2}$ emissions by releasing carbon bound up in $\mathrm{CaCO}_{3}$ to the atmosphere as $\mathrm{CO}_{2}$. An additional 1 to $2 \%$ reduction in efficiency due to $\mathrm{SO}_{\mathrm{x}}$ scrubbing is already included in the conventional coal efficiency estimate of $34.6 \%$.

Cheng (1988) has explored the $\mathrm{CO}_{2}$ emissions reduction potential available from the introduction of advanced electric power generation technologies.

Cheng assumes that 3327 TWh of electricity are required to meet the demands of the NEPP forecast in 1995, and 4542 TWh in 2010. He then removes technological progress from the NEPP forecast of electric power generation and explicitly introduces six new technologies which have the potential for both reducing $\mathrm{CO}_{2}$ emissions and achieving a significant market share in the period to 2010. These technologies are: 


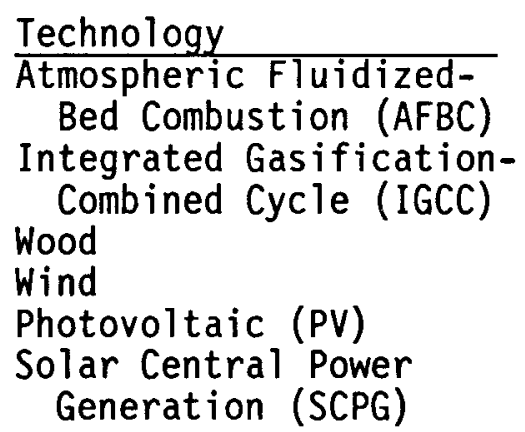

\begin{tabular}{ccc}
$\begin{array}{c}\text { Year of } \\
\text { Inclusion }\end{array}$ & & $\begin{array}{c}\text { Capital Costs } \\
1985 \$ / \mathrm{kW}\end{array}$ \\
\cline { 1 - 1 } & & $1360-1710$ \\
2010 & & $1300-1460$ \\
1995,2010 & & $1740-2290$ \\
1995,2010 & & $1540-3230$ \\
2010 & & $2270-2720$ \\
2010 & & $3030-3350$
\end{tabular}

Note that Cheng makes no attempt to increase the penetration of nuclear power over this time frame on the basis that the lead-time for new nuclear power plants would not allow a significant increase in the number of plants before 2010 .

The key assumptions made by Cheng regarding the penetration of these new technologies are:

\begin{tabular}{|c|c|c|}
\hline Forecast Year & $\begin{array}{l}\text { Cumulative Tota } \\
\text { Solar Technologies } \\
(\% \text { all elec power }) \\
\end{array}$ & $\begin{array}{l}\text { Market Penetration } \\
\text { Fossil Technologies } \\
(\% \text { coal-fired power) }\end{array}$ \\
\hline 1995 & $\begin{array}{l}1-3 \% \\
\text { (Wood and Wind) }\end{array}$ & $\begin{array}{c}1-3 \% \\
(A F B C)\end{array}$ \\
\hline 2010 & $\begin{array}{l}5-10 \% \\
\text { (Wood, Wind, PV, } \\
\text { SCPG) }\end{array}$ & $\begin{array}{c}5-10 \% \\
(A F B C, I G C C)\end{array}$ \\
\hline
\end{tabular}

On this basis Cheng calculates the following $\mathrm{CO}_{2}$ emissions from electric power generation. Results are shown in Table 13 below.

Table 13: $\mathrm{CO}_{2}$ Emissions from Electric Power Generation Consistent with NEPP Power Demands in 1995 and 2010

$(\mathrm{PgC} / \mathrm{yr})$

\begin{tabular}{|c|c|c|c|c|c|c|}
\hline \multirow{5}{*}{$\begin{array}{l}\text { Fuel } \\
\text { Coal } \\
0 \text { i1 } \\
\text { Gas } \\
\text { Total }\end{array}$} & \multicolumn{3}{|c|}{1995} & \multicolumn{3}{|c|}{2010} \\
\hline & High & Low & NEPP & High & Low & NEPF \\
\hline & 0.507 & 0.497 & 0.495 & 0.721 & 0.655 & 0.726 \\
\hline & 0.028 & 0.028 & 0.028 & 0.018 & & 0.018 \\
\hline & $\begin{array}{l}0.434 \\
0.569\end{array}$ & $\begin{array}{l}0.434 \\
0.553\end{array}$ & $\begin{array}{l}0.434 \\
0.567\end{array}$ & $\begin{array}{l}0.026 \\
0.765\end{array}$ & $\begin{array}{l}0.026 \\
0.699\end{array}$ & $\begin{array}{l}0.0<0 \\
0.770\end{array}$ \\
\hline
\end{tabular}

These scenarios show a limited reduction in $\mathrm{CO}_{2}$ emissions. In no case do emissions decline to 1985 levels, $0.433 \mathrm{PgC} / \mathrm{yr}$. And in 1995, Cheng finds that, depending upon the rate of market penetration of new technologies, $\mathrm{CO}_{2}$ emissions from electric power generation could be even higher than indicated 
in the NEPP reference case. Cheng's calculations are comparable to the NEPP high conservation scenario:

\begin{tabular}{|c|c|c|c|}
\hline \multirow[b]{2}{*}{ Year } & \multicolumn{2}{|c|}{ NEPP } & \\
\hline & $\begin{array}{c}\text { Reference } \\
\text { Case }\end{array}$ & $\begin{array}{c}\text { High Eff. } \\
\text { Case }\end{array}$ & Cheng \\
\hline $\begin{array}{l}995 \\
010\end{array}$ & $\begin{array}{l}0.57 \\
0.77\end{array}$ & $\begin{array}{l}0.50 \\
0.67\end{array}$ & $\begin{array}{l}0.57-0.55 \\
0.77-0.70\end{array}$ \\
\hline
\end{tabular}

\section{ENERGY CONSERVATION}

In this section we examine the role that changes in energy demand could have on future U.S. $\mathrm{CO}_{2}$ emissions through changes in the energy intensity of the economy. We will use the term energy conservation potential to mean those improvements in overall economy wide energy intensity brought about by changes in energy efficiency and changes in the composition of final demand. It is important to note that the term conservation here does not mean doing without. The term refers to obtaining the same or increased energy services with less energy input.

We will review various estimates of conservation potential and their $\mathrm{CO}_{2}$ emissions implications and examine in some detail the sources of different energy intensity forecasts developed by two important groups.

\section{Energy Conservation Studies:}

Technologies which could be employed in the period to 2010 to reduce $\mathrm{CO}_{2}$ emissions must already be well along in the development process if they are to play a significant role. The reasoning is simple. No policy designed to effect the $\mathrm{CO}_{2}$ emissions reduction could take effect until 1990. Research indicates that the period over which a new technology penetrates the market is substantial. Marchetti, for example, showed that the characteristic "takeover time," that is, the time it takes for an energy technology to increase its market share from 1 to $50 \%$, is on the order of 30 years for country size systems (Haefele, 1981). The actual time of market penetration can be affected by many factors, including costs and policy measures.

Several engineering/economic studies have attempted to estimate the reduction in U.S. energy consumption that could be effected by the introduction of advanced technologies that simultaneously consume less energy and provide the same or greater energy services. Technologies employed in energy conservation studies represent technological progress. Energy conservation studies examined in the conduct of this study are: NEPP (high efficiency case), Cheng (1988), ERAB (1988), DOE (1987), ACEEE (1988), Goldemberg et al. (1987), which we will refer to as the World Resources Report or simply WRI and Cheng et al. (1985).

NEPP High Efficiency Case: In addition to the base case, which we have used in this paper as our reference forecast of U.S. energy and $\mathrm{CO}_{2}$ emissions, 
NEPP developed High and Low efficiency 8 cases. These two cases represent the alternative propositions that "large efficiency increases will probably not occur", and that "substantial efficiency improvements are still possible." Energy efficiency assumptions were modified so that overall end-use efficiency in the year 2000 was $10 \%$ higher or lower than in the reference case. Assumptions that were varied to construct the high and low cases are given in Table 14 below. No rationale is provided for the selection of those specific rates.

A summary of the High Efficiency NEPP Case is given below in Table 15. As can be seen by comparing the High Efficiency Case to the Reference Case $(\operatorname{NEPP}(\mathrm{RC}))$, there is very little difference between the $\mathrm{CO}_{2}$ emissions generated in the two. $\mathrm{CO}_{2}$ emissions in the High Efficiency Case (NEPP(HE)) are approximately $14.5 \%$ lower than in NEPP $(R C)$, but remains substantially (18\%) above 1985 emissions levels. The NEPP(HE) forecast of $\mathrm{CO}_{2}$ emissions roughly parallels that of primary energy. Primary energy use was $10 \%$ lower in the $\operatorname{NEPP}(\mathrm{HE})$ than in NEPP(RC). The higher rate of reduction in $\mathrm{CO}_{2}$ emissions than in energy consumption is a result of the fact that the reduction in energy use comes disproportionately from reduced coal use. This notwithstanding, the High Efficiency Case provides little cause for optimism about the potential for substantial reductions in $\mathrm{CO}_{2}$ emissions, as compared with 1985 levels, without market intervention in the period to 2010. The NEPP scenarios are discussed in greater detail later in this chapter.

Table 14: Assumptions in NEPP High and Low Efficiency Cases

Discount Rates:

High
Efficiency

Residential

HVAC a

Appliances

Commercial

HVAC a

Appliances \& Lighting

Industrial

Cogeneration

Other End Uses

$15 \% / y r$
$20 \% / y r$

$10 \% / \mathrm{yr}$

$20 \% / y r$

$5 \% / \mathrm{yr}$

$5 \% / y r$

Other Changes:

Industrial Product/Process

Changeb

Transportation MPGC

Auto

Truck

Air

$35 \% / y r$

$50 \% / y r$

$150 \% / \mathrm{yr}$

$35 \% / y r$

$60 \% / y r$

$75 \% / y r$

$15 \% / y r$

$10 \% / y r$

$25 \% / y r$

$20 \% / y r$

Low Efficiency $150 \% / y r$

Notes: a HVAC = Heating, Ventilation and Air Conditioning

$+15 \%$

$-\cdots$

$-15 \%$

$+10 \%$

-...

$-10 \%$

$-12 \%$

$+12 \%$

$-10 \%$

Percent change in the ratio of energy service demand to industrial output from the Reference Case in the year 2000.

c Percent change from Reference Case efficiency in the year 2000.

Source: DOE (1985), Table 4-15, p. 4-28. 
Table 15: NEPP High Efficiency Case $\mathrm{CO}_{2}$ Emissions Forecast (PgC/yr)

\begin{tabular}{llllll} 
Year & $0 i 1$ & Gas & $\frac{\text { Coal }}{0.44}$ & $\frac{\text { Total }}{1.25}$ & $\begin{array}{l}\text { Ref. } \\
\text { Case } \\
\text { NEPP }\end{array}$ \\
\hline 1985 & 0.56 & 0.25 & 0.25 \\
1990 & 0.57 & 0.25 & 0.47 & 1.28 & 1.40 \\
1995 & 0.55 & 0.25 & 0.51 & 1.32 & 1.47 \\
2000 & 0.54 & 0.24 & 0.57 & 1.36 & 1.55 \\
2005 & 0.52 & 0.23 & 0.67 & 1.41 & 1.64 \\
2010 & 0.50 & 0.21 & 0.76 & 1.48 & 1.73
\end{tabular}

Source: Based on D0E (1985). Tables 4-17 and 4-18. Assumes that non-energy fuel uses of energy and venting and flaring forecasts are the same as in the Reference Case.

Cheng: To explore the conservation potential available in the largest $\mathrm{CO}_{2}$ emitting end-use sector, transportation, Cheng (1988) constructed scenarios based on the NEPP forecasts that explicitly include the contributions of advanced technology toward reducing U.S. $\mathrm{CO}_{2}$ emissions in the years 1995 and 2010 .

For the transportation sector, Cheng examines automobiles and trucks only. These two modes of transport dominate the present and NEPP forecasts. Cheng's examination of energy conservation potential includes the effects of both technological efficiency gains and changes in the composition of the automobile fleet.

Cheng's fleet fuel efficiency estimates in miles per gallon are:

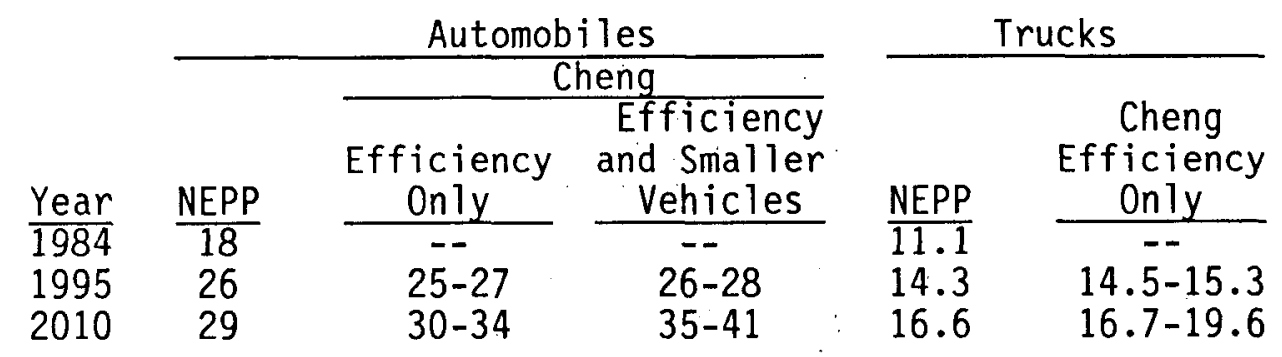

New car fuel efficiencies are much higher than the fleet average efficiency due to a lag in the turn-over of the capital stock. With no change in the composition of the fleet; Cheng estimates that new cars will average $34 \mathrm{mpg}$ in 1995 and $41 \mathrm{mpg}$ in 2010!. With a major shift in the composition of the new car fleet, small cars increase market share from $5 \%$ in 1985 to $50 \%$ in 2010, new car efficiencies are $37 \mathrm{mpg}$ in 1995 and $51 \mathrm{mpg}$ in the year 2010. The difference between new car efficiencies and the fleet efficiency is due entirely to the rate of turnover of the capital stock. The effects of energy 
efficiency improvements and fleet composition on U.S. $\mathrm{CO}_{2}$ emissions are given in Table 16 below:

Table 16: $\mathrm{CO}_{2}$ Emissions from Automobiles and Trucks Consistent with NEPP Transportation Services Demands in 1995 and 2010 $(\mathrm{PgC} / \mathrm{yr})$

\begin{tabular}{|c|c|c|c|c|c|}
\hline & & Automo & iles & & ucks \\
\hline & & & eng & & \\
\hline & NEPP & $\begin{array}{c}\text { Efficiency } \\
\text { Only }\end{array}$ & $\begin{array}{c}\text { Efficiency } \\
\text { and Smaller } \\
\text { Vehicles }\end{array}$ & NEPP & $\begin{array}{c}\text { Cheng } \\
\text { Efficiency } \\
\text { Only }\end{array}$ \\
\hline & 0.15 & $0.15-0.16$ & $0.14-0.15$ & 0.11 & 0.11 \\
\hline & 0.17 & 0.17 & $0.12-0.14$ & 0.15 & $0.12-0.15$ \\
\hline
\end{tabular}

Both the NEPP forecast and the Cheng forecast indicate little increase in $\mathrm{CO}_{2}$ emissions from automobiles between 1985 and 2010. Fleet efficiencies are expected to keep pace with the additional miles driven. In fact the NEPP forecast of transportation related $\mathrm{CO}_{2}$ emissions are actually lower in 1995 than in the year 2010, despite the rise in overall forecast emissions. Cheng shows the importance of the fleet composition. A shift toward smaller cars can have a major impact on future transportation $\mathrm{CO}_{2}$ emissions. While the composition of the fleet is assumed to remain constant for trucks, fuel efficiency improvements are shown to have the potential for holding emissions from trucks approximately constant.

ERAB: As part of its assessment of U.S. energy competitiveness, the Energy Research Advisory Board (ERAB) examined the potential for energy conservation gains in the year 2000. The ERAB report drew upon eight studies summarized in Carl and Sheer (1987). The ERAB findings are summarized in Table 17 below.

The implied $\mathrm{CO}_{2}$ emissions reductions are:

$$
\begin{array}{lll}
\text { 0i1 } & 0.158 & \mathrm{PgC} / \mathrm{yr} \\
\text { Gas } & 0.039 & \mathrm{PgC} / \mathrm{yr} \\
\text { Coal } & 0.186 & \mathrm{PgC} / \mathrm{yr} \\
\hline \text { Sum } & 0.383 & \mathrm{PgC} / \mathrm{yr}
\end{array}
$$

The average year 2000 energy forecast cited by ERAB was 92.5 quads. This compares well with the NEPP year 2000 reference case forecast of 93.7 quads (excluding wood). Applying this potential emissions reduction to the NEPP year $2000 \mathrm{CO}_{2}$ emissions forecast implies that energy conservation could reduce U.S. emissions by $0.38 \mathrm{PgC} / \mathrm{yr}$ to $1.17 \mathrm{PgC} / \mathrm{yr}$. This is a substantially greater reduction of $\mathrm{CO}_{2}$ emissions than in the NEPP High Efficiency Case and is a $10 \%$ reduction from 1985 emissions levels without considering supply side technologies. 
Table 17: ERAB Estimates of U.S. Conservation

Potential for the Year 2000

(quads)

Average Conservation Potential
By End-Use Sector

(2)

Buildings

Transportation

Industry

Total

Average Conservation Potential
By Fuel Type

7.8

$0 i 1$

Gas

2.7

Coal

7.4

other

$\underline{0.5}$

Total

18.4

a Indicates petroleum conservation potential.

b This estimate is artificially low since one of the eight studies included potential industrial savings in the base case.

Note: Conservation potential is defined as the total fuel that can be saved in the year 2000 from improvements in end-use efficiency [see note $8]$ by use of advanced technology and practices. The conservation potential is defined as the difference between base case and conservation case forecasts of energy demand. The results above are calculdted as the average of the fuel savings estimates from eight studies of conservation potential published during the 1979-1987 time period. As a point of reference, the base case consumption forecast varies from 87.0 quads to 110.0 quads with an average of 92.5 quads in these studies.

DOE, Office of Conservation: The DOE Office of Conservation (DOE/OC) annually publishes a multi-year plan which contains estimates of U.S. conservation potential. The time frame of the analysis is the year 2010 and is based on a special DOE/EIA forecast which is similar but not identical to the NEPP forecast. The conservation potential estimates are therefore generally comparable with the scope of this study. The estimates are aggregated on the basis of total energy savings attributable to specific technologies. As the fuel composition of energy savings is important to determining $\mathrm{CO}_{2}$ emissions reduction potential, the calculations based on DOE/OC conservation potential estimates are somewhat more problematical than with other studies in which fuel composition can be discerned. On the other hand, the office's intimate understanding of energy conservation potential for a broad array of diverse technologies adds an important perspective. We have used information contained in DOE (1987) to construct an estimate of year 2010 emissions. These are displayed in Table 18.

The conservation potential estimates developed in Table 18 indicate that U.S. $\mathrm{CO}_{2}$ emissions could be reduced to 1985 levels in the year 2010. While these estimates include the effect reduced end-use energy consumption would have on electric utility fuel requirements, they take no consideration of the additional effects improved electric power generation efficiencies would have on $\mathrm{CO}_{2}$ emissions. 
Table 18: Office of Conservation

Energy Use and $\mathrm{CO}_{2}$ Emissions by Fuel and Sector: 2010

Energy Use (x1015Btu/yr)

Residential

Commercial

Industrial

(Non-Energy Uses)

Transportation

Electric Utilities

Synfuels

Venting \& Flaring

Total

Total (exc. Wood) $\frac{0 \mathrm{i} 1}{0.9}$

1.1

7.8

4.0

14.7

0.9

$-0.6$

0.4

24.8

24.8

\begin{tabular}{r} 
Gas \\
\hline 2.9 \\
2.5 \\
7.4 \\
0.9 \\
0.6 \\
1.8 \\
-0.3 \\
0.1
\end{tabular}

14.9

14.9

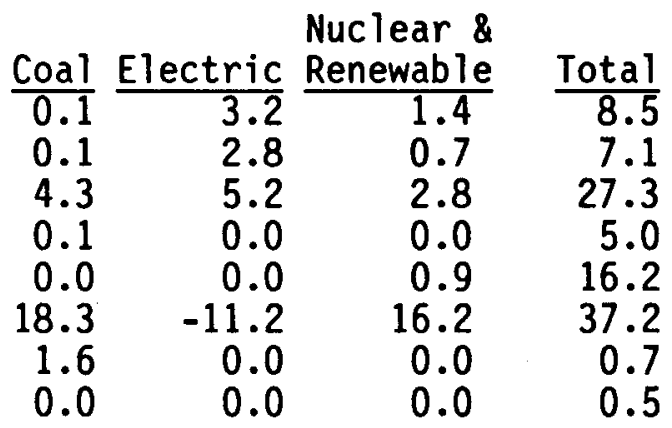

$24.3 \quad-0.0 \quad 21.9$

$24.3 \quad-0.0 \quad 16.2$
85.8

80.1

$\mathrm{CO}_{2}$ Emissions ( $\left.\mathrm{PgC} / \mathrm{yr}\right)$

Residential

Commercial

Industrial

Transportation

Electric Utilities

Synfuels

Venting \& Flaring

Total $\frac{0 i 1}{0.02}$

0.02

0.08

0.30

0.02

$-0.01$

0.01

0.43

0.20

$\frac{\text { Gas }}{0.04}$

0.04

0.09

0.01

0.03

$-0.00$

0.00

0.61

$\frac{\text { Coal }}{0.00}$

$\frac{\text { Total }}{0.06}$

0.06

0.27

0.31

0.50

0.02

0.01

0.04

0.00

1.24

$100 \%$

Notes: Residential and Commercial sectors are taken to be the same as NEPP, with a 25\% reduction in energy use applied to all fuels and electricity based on DOE (1987), p.3-11. Both the industrial sector and non-fuel uses were reduced by $18 \%$ to represent the rate of conservation potential (8.6 quads reduction possible out of a base of 47.4 quads) cited by DOE (1987), p.5-13. DOE (1987), p.414 cites 7.7 quads reduction possible from a base of 26.4 quads consumption of liquids. This same rate was applied to liquids use in the Transportation sector. Reductions in electricity production were applied to coal generating capacity only with the assumption that all electric power was produced at a rate of $30 \%$ efficiency including self use and transmission and distribution losses.

ACEEE: Energy efficiency is the central issue addressed by the American Councilfor an Energy-Efficient Economy. In its recent publication, Chandler et al. (1988), the ACEEE set out the most important policy priorities for continuing recent energy efficiency gains. It provided a set of first priority energy policy recommendations. Rather than attempting to quantify the energy savings of these specific proposals, Chandler et al. estimated what might occur if a national goal of reducing energy intensity by $2.5 \% /$ year were realized 
in the period between the present and the year 2000. The ACEEE extrapolation of energy conservation was compared to, but not based on, a forecast taken from DOE/EIA (1988a). Table 19 displays the ACEEE "High Efficiency" case desegregated into fuel types by R.H. Williams, and associated $\mathrm{CO}_{2}$ emissions.

Table 19: ACEEE High Efficiency Scenario and Associated $\mathrm{CO}_{2}$ Emissions For the Year 2000

\begin{tabular}{|c|c|c|c|c|}
\hline \multirow{7}{*}{$\begin{array}{l}\text { Energy Source } \\
\text { Nuclear } \\
\text { Hydro } \\
\text { Coal } \\
\text { Oil } \\
\text { Natural Gas } \\
\text { Total }\end{array}$} & \multicolumn{2}{|c|}{ Base Casea } & \multicolumn{2}{|c|}{ ACEEE } \\
\hline & $\begin{array}{l}\text { Energy } \\
\text { (Quads) }\end{array}$ & $\begin{array}{c}\mathrm{CO}_{2} \\
(\mathrm{PgC} / \mathrm{yr})\end{array}$ & $\begin{array}{l}\text { Energy } \\
\text { (Quads) }\end{array}$ & $\begin{array}{c}\mathrm{CO}_{2} \\
(\mathrm{PgCl} / \mathrm{yr}\end{array}$ \\
\hline & & & & \\
\hline & & & & \\
\hline & & & & \\
\hline & & & & \\
\hline & $\frac{20.2}{89.6}$ & & $\frac{13.0}{71.2}$ & \\
\hline
\end{tabular}

Source: Chandler et al. (1988) for totals R.H. Williams, personal communication for fuel disaggregation. The ACEEE made no forecast of energy supply by fuel. Williams' fuel disaggregation is consistent with, but was not part of the published study.

a DOE/EIA (1988a)

The DOE/EIA base case, upon which Williams' fuel disaggregation of the ACEEE case was based, is a somewhat lower energy consumption forecast than the NEPP. The associated $\mathrm{CO}_{2}$ emissions are also lower due partly to the lower aggregate energy demand, of the DOE/EIA scenario as compared to NEPP, and partly to the higher demand for oil and lower demand for coal in DOE/EIA. The energy conservation potential displayed in Table 19 is sufficient to maintain $\mathrm{CO}_{2}$ emissions at 1985 levels.

WRI: Goldemberg et al. (1987), (WRI) pursue an explicitly normative approach to the issue of energy intensity. They work from the proposition that energy production and use should be compatible with larger societal goals.

At the most fundamental level the goals of society should be equity, economic efficiency, environmental harmony, long-term viability, self-reliance, and peace. Energy production and use should be compatible with, and if possible contribute to, these societal goals. (WRI, p.v)

WRI therefore constructs a plausible future consistent with the above stated normative goals. Two cases are developed for the U.S. for the year 2020. In the first, per capita income is assumed to increase by $50 \%$ by the year 2020 . In the second, per capita income is assumed to increase by $100 \%$ by the year 2020. Energy and $\mathrm{CO}_{2}$ emissions implications are given in Table 20. 
Table 20: U.S. Energy and $\mathrm{CO}_{2}$ Emissions for the Year 2020:

\begin{tabular}{|c|c|c|c|c|}
\hline \multirow[b]{3}{*}{ Fuel } & \multicolumn{2}{|c|}{ GNP/Cap $+50 \%$} & \multicolumn{2}{|c|}{ GNP/Cap $+100 \%$} \\
\hline & Energy & $\mathrm{C02}$ & Energy & $\mathrm{CO2}$ \\
\hline & (quads) & $(\mathrm{PgC} / \mathrm{yr})$ & (quads) & $(\mathrm{PgC} / \mathrm{yr})$ \\
\hline $0 i 1 \&$ Gas & 24.5 & 0.43 & 26.4 & 0.46 \\
\hline Coal & 10.8 & 0.27 & 12.6 & 0.32 \\
\hline Nuclear & 7.1 & 0.00 & 7.1 & 0.00 \\
\hline Hydro & 1.3 & 0.00 & 1.3 & 0.00 \\
\hline Wind and Photovoltaic & 0.9 & 0.00 & 0.9 & 0.00 \\
\hline Biomass & 4.4 & 0.00 & 4.4 & 0.00 \\
\hline Total & 49.0 & 0.70 & 52.6 & 0.77 \\
\hline
\end{tabular}

Notes: $0 i 1$ \& Gas emissions evaluated on the assumption that oil and gas each contribute half of the total energy in that category. This yields a $\mathrm{CO}_{2}$ emission rate, $0.017354 \mathrm{gC} / \mathrm{Btu}$ for 0 il \& Gas.

It is important to note that this study includes both energy conservation potential and efficiency improvements attributable to the introduction of advanced technology gas turbines (assumed to be $50 \%$ efficient on average), and improvements in coal fired electric power generation (assumed to be $40 \%$ efficient on average). To achieve these energy production efficiency goals, the entire fossil fuel electric generating capacity is replaced. This requires a reversal of the present trend toward power plant life extension.

WRI's is the most optimistic of the studies examined for this report about the prospects for reducing future U.S. $\mathrm{CO}_{2}$ emissions. This study indicates, that $\mathrm{CO}_{2}$ emission reductions of almost $40 \%$ from 1985 levels by the year 2020 are technically feasible and compatible with activity levels necessary to double U.S. per capita GNP. It demonstrates the existence of an array of energy and economic activities significantly different than that in NEPP, but with similar underlying macroeconomic assumptions. For this reason we will examine the construct of this case in comparison with NEPP in some detail in a subsequent section of this chapter, paying particular attention to the comparison between the NEPP High Efficiency case and WRI

Cheng et al.: An earlier DOE sponsored study, Cheng et al. (1986), explored the potential of advances in energy efficiency across a broad range of technologies to reduce U.S. and world $\mathrm{CO}_{2}$ emissions in the year 2050 . While the time frame of this analysis is longer than any other study examined in this paper, their results provide a useful benchmark against which to view other, shorter-term, conservation potential studies.

Cheng et al. compared two cases. The first case forecast $\mathrm{CO}_{2}$ emissions under the assumption that present best available technologies were the norm by the year 2050. The second or reference case, assumed that no technological change occurs after 1975. Each case was developed from the Case B scenario put forward in Edmonds et al. (1984). Cheng et al. modified the Case B scenario to remove the effects of technological change between 1975 and 2050 . It is 
also important to note that the analysis focused exclusively on $\mathrm{CO}_{2}$ emissions from energy end-use and electric power generation. This means that the effects of $\mathrm{CO}_{2}$ emissions from synfuel production are not included in the emissions calculation. Similarly, no attempt was made to discriminate between solids that were in the form of biomass and those in the form of coal. The inclusion of the former consideration would increase the calculated emissions, while inclusion of the latter factor would decrease the calculated emissions. Approximately 75 energy service categories are examined and efficiencies calculated for present technology, achievable efficiency, and theoretical efficiency. Achievable efficiency is defined as "the current predicted value on the basis of the present knowledge on the technology." U.S. energy consumption and end-use $\mathrm{CO}_{2}$ emissions are then recalculated on the assumption that achievable technologies are reached by the year 2050 and that these technologies are the norm by that year.

The consequent fossil fuel $\mathrm{CO}_{2}$ emissions are given in Table 21 below.

Table 21: Year 2050 U.S. Fossil Fuel $\mathrm{CO}_{2}$ Emissions: DOE Case B and Cheng et al. (1986)

\begin{tabular}{|c|c|c|c|}
\hline \multirow[b]{2}{*}{$\begin{array}{l}\text { Direct Consumption } \\
\text { Liquids } \\
\text { Gases } \\
\text { Solids }\end{array}$} & DOE Case B & \multicolumn{2}{|c|}{ Cheng et al. (1986) } \\
\hline & $\begin{array}{l}2.76 \\
(1.29) \\
(0.44) \\
(1.03)\end{array}$ & $\begin{array}{l}3.36 \\
(1.41) \\
(0.54) \\
(1.41)\end{array}$ & $\begin{array}{l}1.46 \\
(0.65) \\
(0.22) \\
(0.59)\end{array}$ \\
\hline Synfuel Conversions & 0.54 & -- & -- \\
\hline$\frac{\text { Biomass Adjustment }}{\text { Total }}$ & $\frac{-0.04}{3.25}$ & $\frac{--}{3.36}$ & $\frac{--}{1.46}$ \\
\hline
\end{tabular}

Note that if the $0.50 \mathrm{PgC} / \mathrm{yr}$ from synfuel conversions and biomass adjustment are added to the Cheng et al. totals, that total emissions in the technological improvement case (shown in the column headed: W.Tech.Chng.) increase to $1.96 \mathrm{PgC} / \mathrm{yr}$. This can be interpreted as an upper bound on U.S. $\mathrm{CO}_{2}$ emissions within the context of this analysis since the improved energy intensity should reduce the demand for synfuels and therefore reduce the additional emissions from this activity.

It should also be noted that cheng et al. calculate that an additional $0.2 \mathrm{PgC} / \mathrm{yr}$ could be saved by an accelerated introduction of nuclear power to displace coal fired capacity.

\section{A General Comparison of NEPP and WRI:}

In this section, we compare the analysis, approach and assumptions of the NEPP and WRI studies, which show the range of higher and lower $\mathrm{CO}_{2}$ emissions reduction potentials. Particular attention will be paid to the role of energy intensity in the model calculations and the structural, 
technology and behavioral assumptions used for the various intensity parameters.

This discussion will not include a quantitative evaluation of the internal calculations of the two models; the purpose of the comparison is to identify the basis for differences in the overall energy demand projections by end-use sector.

The following convention is used to refer to these studies:

(1) NEPP(RC): the Reference Case demand forecasts in National Energy Policy Plan, (DOE, 1985) and the energy/economic modelling on which they are based (Applied Energy Services, 1986a and 1986b),

(2) NEPP (HE): the NEPP High Efficiency Case, and

(3) WRI: the future U.S. energy demand scenario described in the source, WRI.

Comparison Approach: The basic approach to comparing the results of the two models is to decompose the end-use energy demand projections into their principle causal components or factors. For any particular energy end-use demand (consumption) considered, this decomposition may be written as:

$$
\text { energy demand = activity level } \mathrm{x} \text { energy intensity. }
$$

Our analysis will be conducted at two levels of aggregation: the total economy, and by major end-use sector (residential, commercial, industrial, and transportation). Aggregate results are calculated to indicate broad trends in national energy intensity and use; in this case, the level of activity is the total output of the economy or GNP. Major energy end-use sectors are examined to provide further insight into detailed differences between the two approaches. Major activities are identified for each of the energy end use sectors and associated energy services; examples of the activities requiring energy services include level or value of industrial production (industrial sector), floor space heated or cooled (residential or commercial buildings sector), vehicle miles traveled (transportation sector) and electric power delivered (energy transformation sector).

Since the two models forecast energy futures at two different points in time (NEPP produces forecasts for the year 2010 and the WRI results are for the year 2020), annual rates of growth are used to put model parameters such as GNP and total energy demand, on comparable terms.9

Comparison of Results: A summary of the general characteristics for the NEPP and WRI models is shown in Table 22. As this table indicates, these two studies represent very different approaches to the question of conservation potential, so it is not surprising that their results are so far apart. 
Table 22: Comparison of General Analysis

Features in NEPP and WRI

\begin{tabular}{|c|c|c|}
\hline Issue & NEPP & WRI \\
\hline Base Year & 1984 & 1980 \\
\hline $\begin{array}{l}\text { Terminal } \\
\text { Year }\end{array}$ & 2010 & 2020 \\
\hline Approach & $\begin{array}{l}\text { Behavioral--Forecasts } \\
\text { U.S. energy production } \\
\text { and use under various } \\
\text { assumptions about } \\
\text { technological } \\
\text { availability and } \\
\text { external circumstances. }\end{array}$ & $\begin{array}{l}\text { Normative--Specifies a } \\
\text { feasible energy future } \\
\text { consistent with broad } \\
\text { societal goals of economic } \\
\text { efficiency, equity, } \\
\text { environmental soundness, } \\
\text { self reliance, peace and } \\
\text { long-term viability. It } \\
\text { includes policy } \\
\text { prescriptions to achieve } \\
\text { these objectives, but } \\
\text { detailed transition states } \\
\text { of the energy system are } \\
\text { not included. The year } \\
\text { 2020 was chosen as the } \\
\text { forecast year because it } \\
\text { is assumed that capital } \\
\text { stocks can be largely } \\
\text { replaced between the present } \\
\text { and that future date. } \\
\text { Energy service demands are } \\
\text { developed based on an assumed } \\
\text { future level of per capita } \\
\text { income. The analysis then } \\
\text { seeks to identify } \\
\text { technologies consistent } \\
\text { with that income level and } \\
\text { the above mentioned societal } \\
\text { goals. }\end{array}$ \\
\hline
\end{tabular}




\begin{tabular}{|c|c|c|}
\hline Issue & NEPP & WRI \\
\hline $\begin{array}{l}\text { Energy } \\
\text { Intensity }\end{array}$ & $\begin{array}{l}\text { Assumes that the } \\
\text { historical trend in the } \\
\text { relationship between the } \\
\text { demand for energy } \\
\text { services and manufacture } \\
\text { will continue. That is, } \\
\text { even if energy prices } \\
\text { remain constant, } \\
\text { increased production } \\
\text { will result in less than } \\
\text { proportional increases } \\
\text { in the demand for energy } \\
\text { services, as changes in } \\
\text { industrial composition } \\
\text { are projected to } \\
\text { continue. The } \\
\text { projection does not } \\
\text { analyze this trend in } \\
\text { detail but represents } \\
\text { the aggregate effect } \\
\text { based on many other } \\
\text { detailed studies of } \\
\text { future industrial energy } \\
\text { demand. }\end{array}$ & $\begin{array}{l}\text { Assumes that the production } \\
\text { of basic materials will } \\
\text { not grow between the present } \\
\text { and the year } 2000 \text {. From } 2000 \\
\text { to } 2020 \text { materials production } \\
\text { increases once again at an } \\
\text { average annual rate of } \\
1.7 \% \text {. Demands for all } \\
\text { energy-intensive appliances, } \\
\text { except air conditioning } \\
\text { are assumed to saturate by } \\
\text { the year } 2020 \text {. The number } \\
\text { of light vehicles per adult } \\
\text { is } 0.8 \text { in } 2020 \text { (about the } \\
\text { same as in } 1980 \text { ) The } \\
\text { usage rate for light vehicles } \\
\text { remains constant at } 10,600 \\
\text { miles per vehicle. New } \\
\text { GNP is assumed to be created } \\
\text { by higher value-added, and } \\
\text { lower energy-intensity, } \\
\text { products such as } \\
\text { electronics. }\end{array}$ \\
\hline $\begin{array}{l}\text { Technology } \\
\text { Penetra- } \\
\text { tion/Con- } \\
\text { sumer } \\
\text { Discount } \\
\text { Rate }\end{array}$ & $\begin{array}{l}\text { Assumes technology } \\
\text { penetration is } \\
\text { constrained by consumer } \\
\text { discount rates } \\
\text { consistent with } \\
\text { historical behavior. In } \\
\text { most sectors discount } \\
\text { rates are significantly } \\
\text { higher than } 10 \% \text { which is } \\
\text { used in standard } \\
\text { analyses. }\end{array}$ & $\begin{array}{l}\text { Assumes that capital stocks } \\
\text { are retired as scheduled } \\
\text { and replaced by energy } \\
\text { efficient technology. The } \\
\text { role of the discount rate } \\
\text { is to demonstrate economic } \\
\text { viability of new } \\
\text { technologies. }\end{array}$ \\
\hline Policy & $\begin{array}{l}\text { Assumes no substantial } \\
\text { change in energy policy } \\
\text { from that in effect in } \\
1984 \text {. }\end{array}$ & $\begin{array}{l}\text { While much of the } \\
\text { improvement in energy } \\
\text { intensity and } \mathrm{CO}_{2} \text { emissions } \\
\text { is expected to occur as a } \\
\text { natural outgrowth of } \\
\text { technological improvement } \\
\text { and consumer choice, } \\
\text { substantial policy changes } \\
\text { are required to achieve } \\
\text { the full gains. }\end{array}$ \\
\hline
\end{tabular}


Aggregate Energy Economic Assumptions: The aggregate economic results and assumptions for the NEPP and WRI studies are shown in Table 23. Two NEPP cases (the Reference Case and High Efficiency Case) and two WRI cases are shown (the Low Growth case and High Growth case). The WRI low growth case assumes per capita GNP growth of 50\% from the 1980 level and the High Growth scenario assumes per capita GNP growth of $100 \%$ from the 1980 level. The role of the principle economic factors in the two models is summarized below:

Table 23: Comparison of Aggregate Energy and Economic Performance in NEPP AND WRI a (Annual Growth Rate from Base Year to Terminal Year $(\%$ per year))

\begin{tabular}{|c|c|c|c|c|}
\hline & & & & \\
\hline & & & WRI & WRI \\
\hline Factor & $(\mathrm{RC})^{b}$ & (HE)C & $\begin{array}{l}\text { low } \\
\text { growth }\end{array}$ & $\begin{array}{l}\text { Mign } \\
\text { growth }\end{array}$ \\
\hline Primary Energy Use & $1.4 \%$ & $\frac{11}{1.0 \%}$ & $\frac{10011}{-1.1 \%}$ & $\frac{1 \% 0.11}{-0.9 \%}$ \\
\hline Final Energy Use & $1.0 \%$ & $0.5 \%$ & $-1.2 \%$ & $-1.0 \%$ \\
\hline $\begin{array}{l}\text { GNP } \\
\text { Population }\end{array}$ & $\begin{array}{l}2.5 \% \\
0.69 \%\end{array}$ & $\begin{array}{l}2.7 \% \\
0.69 \%\end{array}$ & $\begin{array}{l}1.7 \% \\
0.66 \%\end{array}$ & $\begin{array}{l}2.5 \% \\
0.66 \%\end{array}$ \\
\hline Primary Energy & & & & \\
\hline $\begin{array}{l}\text { Intensity } \\
\text { (quads/GNP, '84 \$) }\end{array}$ & $-1.2 \%$ & $-1.7 \%$ & $-2.7 \%$ & $-3.3 \%$ \\
\hline $\begin{array}{l}\text { Per capita GNP } \\
\text { Per capita Final }\end{array}$ & $2.0 \%$ & $2.0 \%$ & $1.0 \%$ & $1.8 \%$ \\
\hline Energy Use & $0.3 \%$ & $-0.2 \%$ & $-1.8 \%$ & $-1.7 \%$ \\
\hline NOTES: & & & & \\
\hline $\begin{array}{ll}\text { a } & \text { base year: } \\
\text { b terminal year: } \\
\text { b RC = Reference } \\
\text { c } \mathrm{HE}=\text { High Effici }\end{array}$ & $\begin{array}{l}\text { NEPP - } 1984 \\
\text { NEPP - } 2010 \\
\text { ase } \\
\text { ency Case }\end{array}$ & $\begin{array}{l}\text { WRI }-1980 \\
\text { WRI }-2020\end{array}$ & & \\
\hline
\end{tabular}

Aggregate Energy Demand: The results in Table 23 indicate large differences in the two models. The WRI model shows a decline in energy growth rates while the NEPP model indicates an increase in rates, which is typical of past U.S. experience.

Population and GNP: These are two key aggregate activity variables in the energy demand equation and tabulated values indicate no significant differences between the models with the exception of the WRI low growth case. The 1.7\% figure is significantly below the other cases and would result in large total energy use reductions.

Aggregate Energy Intensity: The energy intensities shown in the table reveal that this variable is the principle source of the large differences in energy demand. The WRI rates are about $60 \%$ to $95 \%$ larger than those of NEPP(HE). As a baseline, the NEPP(HE) energy intensities compare favorably with the historical record of 1.9$2.0 \%$ for U.S. E/GNP ratios presented in Table 6 . The WRI figures 
are $40-150 \%$ larger than the past average, al though they are close to performance in recent years (1980-1985).

End-Use Sector Results: Table 24 contains the energy demand results and annual growth rates for each end use sector. The energy intensity improvements from 1984 to 2010 for NEPP are implemented principally through changes in the model's consumer discount rate for purchases of energy efficient equipment already in the available technology set. No new technology beyond what was al ready available for the NEPP Reference Case (approximately 1984 vintage) is introduced for NEPP(HE). On the other hand, some new and highly efficient technologies are assumed for extensive use in the WRI model.

Direct comparisons of the detailed technology assumptions for these two models is beyond the scope of this study. However, general comments on the major technical assumptions leading to the contents of Table 24 are discussed by end use sector.

Table 24: Comparison of End Use Energy Results in NEPP and WRI a (Annual Growth Rate from Base Year to Terminal Year)

\begin{tabular}{|c|c|c|c|c|}
\hline & $\begin{array}{l}\text { NEPP } \\
\text { (RC) }\end{array}$ & $\begin{array}{c}\text { NEPP } \\
\text { (HE) }\end{array}$ & $\begin{array}{l}\text { WRI Low } \\
\text { Growth }\end{array}$ & $\begin{array}{l}\text { WRI High } \\
\text { Growth }\end{array}$ \\
\hline $\begin{array}{l}\frac{\text { Total }}{\text { Annual Final Energy Use }} \\
\text { Energy Intensity }\end{array}$ & $\begin{array}{r}1.0 \% \\
-1.2 \%\end{array}$ & $\begin{array}{r}0.5 \% \\
-1.7 \%\end{array}$ & $\begin{array}{l}-1.2 \% \\
-2.7 \%\end{array}$ & $\begin{array}{l}-1.0 \% \\
-3.3 \%\end{array}$ \\
\hline $\begin{array}{l}\text { Residential } \\
\text { Rnnual Final Energy Use } \\
\text { Energy Intensity }\end{array}$ & $\begin{array}{r}0.5 \% \\
-0.6 \%\end{array}$ & $\begin{array}{l}-0.2 \% \\
-1.2 \%\end{array}$ & $\begin{array}{l}-1.7 \% \\
-2.7 \%\end{array}$ & $\begin{array}{l}-1.7 \% \\
-2.7 \%\end{array}$ \\
\hline $\begin{array}{l}\text { Commercial c } \\
\text { Annual Final Energy Use } \\
\text { Energy Intensity }\end{array}$ & $\begin{array}{r}1.7 \% \\
-0.7 \%\end{array}$ & $\begin{array}{r}1.3 \% \\
-1.0 \%\end{array}$ & $\begin{array}{l}-1.7 \% \\
-2.7 \%\end{array}$ & $\begin{array}{l}-1.7 \% \\
-2.7 \%\end{array}$ \\
\hline $\begin{array}{l}\text { Industrial d } \\
\text { Annual Final Energy Use } \\
\text { Energy Intensity }\end{array}$ & $\begin{array}{r}1.5 \% \\
-1.8 \%\end{array}$ & $\begin{array}{r}0.9 \% \\
-2.4 \%\end{array}$ & $\begin{array}{l}-0.9 \% \\
-2.3 \%\end{array}$ & $\begin{array}{l}-0.7 \% \\
-2.8 \%\end{array}$ \\
\hline $\begin{array}{l}\text { Transportation e } \\
\text { Annual Final Energy Use } \\
\text { Energy Intensity }\end{array}$ & $\begin{array}{r}0.5 \% \\
-1.7 \%\end{array}$ & $\begin{array}{r}0.1 \% \\
-1.7 \%\end{array}$ & $\begin{array}{l}-1.3 \% \\
-4.0 \%\end{array}$ & $\begin{array}{l}-0.9 \% \\
-4.0 \%\end{array}$ \\
\hline
\end{tabular}

Residential buildings: In the NEPP(HE), energy intensity changes are implemented by reducing the discount rate for consumer purchases of energy efficient equipment; this rate is assumed to be lower in $\operatorname{NEPP}(H E)$ than in NEPP (RC) (e.g. NEPP(RC) is $35 \%$ and NEPP (HE) is $15 \%$ per year for heating, ventilation and air conditioning (HVAC), as shown in Table 14). 
In the WRI study, the key energy intensity assumptions are:

1. All major appliances, except air conditioning, achieve $100 \%$ market penetration by 2020 . The figure for air conditioning is $75 \%$ penetration.

2. Regarding heating loads, the required output of space-heating systems in fuel-heated homes constructed before 1981 is assumed to be reduced by $30 \%$ by 2020 ; no corresponding savings are assumed for electric heated homes.

3. The norm for heating system performance is assumed to be equal to the most efficient furnaces and heat pumps commercially available in 1982. All other end use energy performance is assumed to be that of the most efficient technology presently available.

Commercial Buildings: For NEPP(HE), the energy intensity gains are implemented by increasing installations of energy efficient technology through the assumed consumer discount rate, as shown in Table 14 .

The WRI study assumptions for energy intensity $\left(G j / \mathrm{m}^{2} /\right.$ year) are:

\begin{tabular}{ccc} 
Vintage & Fuels & Elec. \\
\cline { 2 - 4 } pre-1980 & 0.46 & 0.23 \\
$1980-1990$ & 0.10 & 0.43 \\
$1990-2020$ & 0.04 & 0.28
\end{tabular}

Industry: In NEPP(HE), the improvement in energy intensity is assumed to be $15 \%$ over the NEPP (RC) in the year 2000 . For WRI energy intensity is assumed to be reduced $50 \%$ from 1980 to 2020 in the industrial sector, which is divided into three major sub-components:

BMP: basic materials processing,

MAC: mining, agriculture and construction, and

OMFG: other manufacturing.

Transportation: For NEPP (HE), the assumed improvement in energy intensity over the NEPP(RC) is $10 \%$ for autos in the year 2000 . The NEPP(RC) fuel economy assumption is a fleet average of $29.3 \mathrm{mpg}$ in 2010 .

The energy intensity assumptions for the WRI study include a fuel economy for the average light vehicle of $75 \mathrm{mpg}$; the reduction in energy intensity for both truck and air passenger travel is $50 \%$.

Principal Modelling Differences--Economic Structure: Large differences in assumed economic structure are apparent in the two models. The NEPP model 
assumes continued change in the structure of each sector consistent with postWorld War II trends. The WRI model assumes major economic structural changes, particularly in the industrial sector (Williams and Larson, 1987). These two models treat the industrial sectors in very different ways.

The WRI study assumed that the product mix of the industrial sector changes substantially from the 1980 time period, based primarily on a continuing shift in the economy away from energy intensive BMP production toward more inherently energy efficient OMFG output, which involves assembly and finishing operations. The BMP and MAC sectors are assumed at zero growth per capita, or they grow only as fast as population.

Principal Modelling Differences--Technology: The technology assumptions are very different for these two models and form the principle basis for explaining the differences in energy intensity results. Two aspects of the technology contribution are important: the set of technology candidates which is assumed available for use in the model and the technology selection from that set, that is put into practice by the model to meet energy service demand. These factors represent, first, the technological "state of the art," and second, the criteria by which technologies are chosen for each type of energy service demand.

The NEPP model uses a different set of technology candidates than the WRI study. The NEPP technology candidates are embedded in a series of conservation supply functions (Btu's saved vs. cost of the savings) for each energy service demand; the functions are defined by successive application of a particular efficient technology (and fuel) from a set of technologies in the order from most to least cost-effective. These supply curves include a technology set which is fixed throughout the model time horizon and which does not include some of the advanced technologies used in the WRI model. The criteria for technology selection to achieve savings for any energy service is minimum total cost (least cost) to meet service demand, where cost is defined as the total life cycle capital and operating costs.

For the WRI case, the technology candidate set is defined using best currently known or projected practice. This set includes some advanced technologies not used by NEPP. Moreover, these technologies are assumed to be used in a different optimal way compared to NEPP. Here the criterion for technology selection appears to be maximum energy efficiency, provided the choice is judged to be cost-effective. The role of the interest rate is to insure economic viability for energy efficient technologies. (See consumer discount rate discussion below.)

These modelling differences mean that the technology (and fuel) used for a given energy service demand in the WRI model may be different from NEPP, because the technology set, and the technology selection criterion are significantly different in the two models.

Principle Modelling Differences--Consumer Discount Rates: Each of these models uses the concept of a consumer discount rate in the determination of the penetration of technologies into the energy demand market place. Supply constraints are assumed not to limit technology availability. The discount 
rate models the behavior of consumers in both installing new efficient technology and operating it in an efficient manner.

The NEPP model assumes discount rates from $5-20 \%$ for NEPP (HE) $(10 \%$ to $60 \%$ for NEPP $(R C)$ ) (DOE, 1985, p 4-28). The WRI model assumes discount rates of $5-10 \%$ (WRI, p.109). The effect of the lower "high end" rate (10\% vs. $20 \%)$ in the WRI case is to allow introduction of some advanced efficient technologies more rapidly or in larger quantities than in the NEPP cases.

Comparison Conclusions: Taken together, the above factors indicate fundamental differences in the assumptions determining energy intensity in the WRI and NEPP models. These differences occur in the principle determinants of aggregate energy intensity, namely, the structural characteristics of energy service demand (activity level), the type of advanced technology available for efficiency improvements, and the consumer behavior (via the discount rate) to install and operate new technology.

Very important differences occur in energy intensity (see Table 24) and two aspects of the models seem to explain the differences. First, the NEPP model does not include several of the advanced efficient technologies that are available in the WRI scenario; examples include use of very high mileage automobiles, very high efficiency lighting and ISTIG units for power generation. Second, the extent of penetration of the available efficient technologies into the market place, as indicated roughly by the consumer discount rate for purchasing energy savings, (see Table 14 for NEPP assumptions), is quite different in these models. The NEPP model introduces new technology more gradually than WRI, through more restrictive discount rate assumptions.

To qualify their key energy intensity assumptions, the WRI authors state that the areas of the WRI projection that are most uncertain include the energy intensities for commercial buildings and automobiles and the growth of the basic materials processing sector of industry (WRI, 1988, p.176).

As indicated earlier, this summary of the model differences is qualitative in nature; it does not include any direct comparison of either the specific energy technologies assumed or the specific calculations used in these models. That level of detail was beyond the scope of this analysis. However, such a quantitative evaluation of the models would be useful for a more thorough understanding of the quantitative contributions to $\mathrm{CO}_{2}$ emissions differences from differences in: 1. Energy technology assumptions, 2. assumptions regarding structural change, and 3 . activity level assumptions.

\section{Conclusions:}

Three major conclusions can be drawn from the foregoing examination of energy conservation potential and its implications for U.S. $\mathrm{CO}_{2}$ emissions reduction in the period to 2010 .

1. $\mathrm{CO}_{2}$ emissions are likely to rise significantly from present levels in the absence of the types of scenarios used by WRI. Both the NEPP 
Reference Case and NEPP High Efficiency Case forecast higher U.S. $\mathrm{CO}_{2}$ emissions in the assumptions period to 2010.

2. The conservation potential studies we examined indicate that level U.S. $\mathrm{CO}_{2}$ emissions are potentially achievable in the period to 2010 . Level U.S. $\mathrm{CO}_{2}$ emissions were achieved between 1975 and 1985.

3. Reductions in U.S. $\mathrm{CO}_{2}$ emissions of up to $40 \%$ may be technically feasible in the period to 2020, but would require accelerated market penetration of existent, but as yet undeployed technologies, and a sustained rate of energy intensity reduction greater than that experienced in the period 1980 to 1985 if levels of GNP growth similar to those forecast in NEPP are to be achieved.

5. THE FEASIBILITY AND GLOBAL IMPACT OF REDUCING U.S. CO2 EMISSIONS

In this section we bring together the estimates of conservation potential and near term supply side $\mathrm{CO}_{2}$ emissions reducing technologies to examine the initial question: Can the U.S. reduce $\mathrm{CO}_{2}$ emissions by 10,25 , or $50 \%$ by either the year 1995 or 2010? In addition, we explore the effect reductions in U.S. $\mathrm{CO}_{2}$ emissions might have on global emissions rates.

Estimates of U.S. CO2 Emissions Reduction Potential:

Table 25 displays the forecast $\mathrm{CO}_{2}$ emissions associated with alternative energy intensity reduction analyses, which include both conservation and the introduction of new natural gas turbine technologies. We recall that 1985 emissions were approximately $1.25 \mathrm{PgC} / \mathrm{yr}$ and that the emissions reduction targets given in Table 2 are respectively:

\begin{tabular}{|c|c|}
\hline $\begin{array}{l}\mathrm{CO}_{2} \text { REDUCTION } \\
\text { TARGET } \\
\end{array}$ & $\begin{array}{l}\text { TOTAL EMISSION } \\
(\mathrm{PgC} / \mathrm{yr}) \\
\end{array}$ \\
\hline $\begin{array}{c}0 \% \\
10 \% \\
25 \% \\
50 \%\end{array}$ & $\begin{array}{l}1.25 \\
1.13 \\
0.94 \\
0.63\end{array}$ \\
\hline
\end{tabular}

Most energy intensity studies reviewed here indicate that maintaining U.S. $\mathrm{CO}_{2}$ emissions at 1985 levels is technically feasible. The ERAB and DOE/OC studies indicate that emissions could be reduced below 1985 levels on the basis of conservation potential only, that is without taking advantage of energy efficiency opportunities available in electric power generation. WRI goes beyond to describe an energy system that produces only $60 \%$ of the 1985 emission levels with a GNP similar to that in NEPP. As noted earlier, these studies do not adequately address the costs of achieving this conservation potential.

There is also general agreement in several of these studies that $\mathrm{CO}_{2}$ emissions rates are likely to rise without energy policy intervention. Two 
of the studies, ACEEE (1988) and WRI, offer explicit policy recommendations to affect the reduction in energy intensity.

In the period to 2010, energy end-use intensity reductions appear to have a larger role in reducing potential $\mathrm{CO}_{2}$ emissions than fuel switching and energy supply technologies. A rough idea of the relative contributions of these two sources of $\mathrm{CO}_{2}$ emissions reductions can be developed by examining those studies which calculate measures sequentially, for example, the ACEEE study, Chandler et al. (1988) and our own calculation based on DOE/OC (1987). In both cases (see Table 25) the difference between the base case $\mathrm{CO}_{2}$ emissions forecast and the level of emissions after end-use energy intensity reductions have been introduced, represented more than $80 \%$ of the total potential reduction in $\mathrm{CO}_{2} .10$

Table 25: Historical $\mathrm{CO}_{2}$ Emissions and Those Associated With Various Energy Intensity Reduction Studies

$(\mathrm{PgC} / \mathrm{yr})$

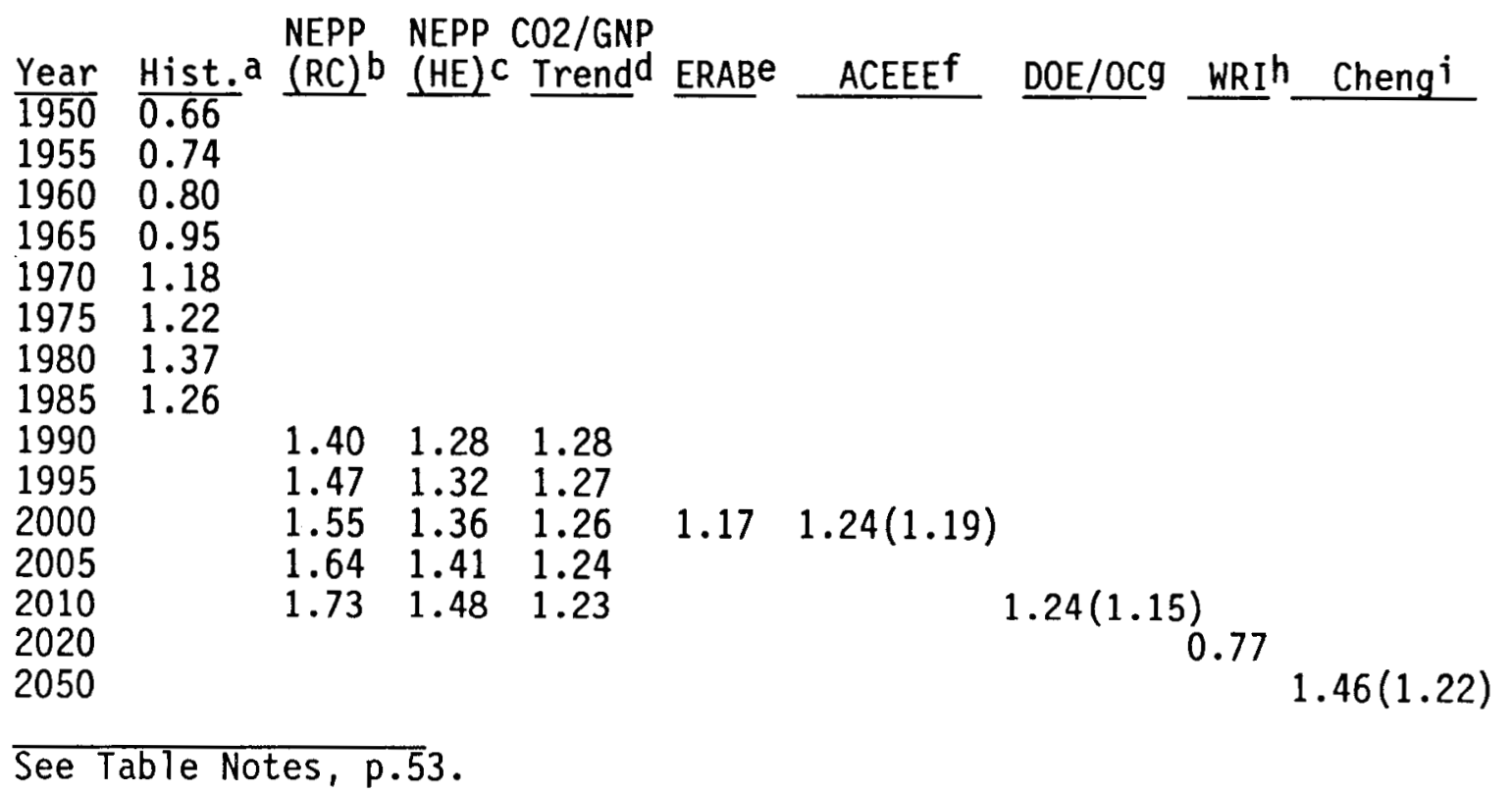

The conference statement of the Toronto climate conference, The Changing Atmosphere: Implications for Global Security, called on governments to "Reduce $\mathrm{CO}_{2}$ emissions by approximately 20 percent of 1988 levels by the year 2005 as an initial global goal." In addition it directed governments and industry to seek about one-half of this reduction from energy efficiency and other conservation measures, and the other half from modifications in supply. In light of the foregoing calculations, $\mathrm{CO}_{2}$ emissions reduction potential does not seem to be available in equal measure from both energy conservation and energy supply in the period to 2010. Greater potential seems available from energy conservation opportunities. 
The issue of economic cost is not dealt with adequately in the studies we reviewed. Several of the studies, notably DOE (1987), WRI , Cheng et al. (1986), and Cheng (1988), include estimates of costs of energy conserving technologies. These studies include calculations of the capital costs and/or the levelized cost of operating the technology. This is insufficient to calculate the true economic (alternative) cost of introducing the technology which can be either positive or negative.

WRI, for example, assumes a level of income and calculates the energy required by that level of economic activity. Demonstrating that technologies exist which, if fully deployed, might reduce $\mathrm{CO}_{2}$ emissions substantially is only half the problem. The companion problem is also important. It is also necessary to show that measures necessary to deploy the new technologies are consistent with the originally hypothesized GNP. Would, for example, the capital requirements needed to deploy the technology cause productive resources to be diverted from other activities and thus lower labor productivity, and thereby GNP?

Calculating the cost of energy conservation requires that two alternative states of the energy-economic system be compared, one with the new energy conserving technology and any policy instruments that are applied to effect its introduction, and the other without. The difference in the value of goods and services (including both marketed and non-marketed, e.g. environmental quality) available under the two states, is a measure of the cost (or benefit) of the technology and/or policy instrument. Technologies that represent technological progress and policies that improve economic performance will have negative costs, while those which require tradeoffs will have positive costs.

The market penetration issue is also inadequately resolved in the analyses we reviewed. This issue is critical to the determination of the cost of achieving $\mathrm{CO}_{2}$ emissions reduction goals. Only NEPP attempts to model explicitly the process of market penetration of new technologies. But the selection of technologies in NEPP is limited. Some of the most important conservation technologies in WRI are not included in the NEPP forecasts. On the other hand, the analytical techniques employed by WRI do not include explicit consideration of the mechanism by which technologies achieve market share and supplant one another. Cheng brings the importance of market penetration assumptions home in his analys is of the transportation sector. Here he showed the differential effects of changing automobile fleet composition.

Another behavioral issue that is an important consideration in determining the feasibility of reducing $\mathrm{CO}_{2}$ emissions is the effect new, more efficient technologies will have on the overall demand for energy services. Any technology which is more efficient, reduces the cost of providing energy services. This reduction in cost will, other things equal, increase the demand for that service. For example, if an increase in efficiency in electric power generation were to lower the cost of generating electricity, then that decreased cost (and price) of electricity will increase the quantity demanded of electricity, other things equal. None of the studies examined during the course of this analysis, except NEPP, includes such feedbacks. The qualitative 
nature of this effect is clear. In general the increase in demand resulting from an increase in energy efficiency will wipe out some, but not all of the gains from the technological change.

Similarly, no study we examined considered the effect improved energy productivity might have on other factor productivity such as labor. A positive correlation would mean that improved energy efficiency could lead to higher GNP and therefore to less overall energy savings than anticipated.

The Effect of U.S. C02 Emissions Reductions on Global Emissions:

There are limits to the amount the United States could reduce global emissions if it acted alone, even though the U.S. is the largest single contributor of fossil fuel $\mathrm{CO}_{2}$ emissions in the world.

In 1950 U.S. emissions were approximately $40 \%$ of global fossil fuel emissions. By 1975 this share had fallen to approximately $25 \%$ of global emissions. Since that time the U.S. share has declined still further, remaining at about $22 \%$ of the global total. See Kellogg et al. (1987). $B$ in Edmonds et al. (1984) shows the U.S. share of the global total is remaining at approximately 20 to $25 \%$ in the period to 2075 .

There are three effects of unilateral U.S. $\mathrm{CO}_{2}$ emissions reductions on global emissions: 1 . direct, 2 . indirect through energy demand, and 3 . indirect through technology and leadership. The direct effects can be calculated straightforwardly. Assume that the U.S. share of global emissions were to remain at $22 \%$ under the NEPP Reference Case emissions scenario during the period to 2010. Holding emissions constant at 1985 levels represents a reduction of $15 \%$ from NEPP forecast emissions in 1995 and $28 \%$ from NEPP forecast emissions in 2010. Assuming no indirect effects, global emissions would continue to grow and the reference global emission would be deflected by only $3 \%$ in 1995 and $6 \%$ in the year 2010.11 Even in the case where U.S. emissions are reduced by $50 \%$ from 1985 levels, global emissions continue to grow and the reference global emission would be deflected by less than $15 \%$ in the year 2010. It is important to note that the reduction in global emissions cited here refers to forecast emissions not the present level.

Significant indirect effects are also possible. Edmonds and Reilly (1983) demonstrated that unilateral reductions in energy consumption produced a smaller reduction in global emissions than the reduction in U.S. emissions. This result is due to the fact that reductions in U.S. emissions lowered global energy demand, which in turn lowered global energy prices. This in turn increased the quantity of energy demanded in the rest of the world thereby increasing rest of the world $\mathrm{CO}_{2}$ emissions. Rest of the world $\mathrm{CO}_{2}$ cannot rise as much as the U.S. reduction in $\mathrm{CO}_{2}$ emissions that precipitated it, but the secondary effect can be important.

The other indirect effect that can also be important works in the opposite direction. If the U.S. introduces technological improvements in the reduction of $\mathrm{CO}_{2}$ emissions, the cost reductions and competitive advantage that they give U.S. firms will spur imitation by competitors. To the extent that this 
effect operates it reinforces a reduction in U.S. emissions. The U.S. leadership position in the world can also be important. The policies it sets and the directions it takes can help determine the directions that other nations follow. This effect would also reinforce any reductions that the U.S. made, but the effect is difficult to predict and impossible to forecast quantitatively. 


\section{NOTES}

1 Global emissions are based on the following calculations:

Global energy production ( $x 1015 \mathrm{Btu} / \mathrm{yr}$ )

$\begin{array}{ll}\text { Oil } & 119.96 \\ \text { (Feedstocks) } & 17.11 \\ \text { Gas } & 60.28 \\ \text { Venting \& Flaring } & 3.59 \\ \text { Coal } & 85.83\end{array}$

$0 i l$ production includes crude oil and natural gas liquids. Feedstocks are petroleum feedstocks only. They are calculated on the basis of 1984 rates: $8.497 \mathrm{mbd}$ of oil used for "other" purposes from primary production of $59.578 \mathrm{mbd}$. 1985 venting and flaring are similarly estimated on the basis of 1984 rates: 3.533 tcf vented and flared with dry gas production of $59.268 \mathrm{tcf}$. Emissions coefficients are as follows: $0 i l=0.020256$ $\mathrm{gC} / \mathrm{Btu}$, gas $=0.0144535 \mathrm{gC} / \mathrm{Btu}$, and coal $=0.025109 \mathrm{gC} / \mathrm{Btu}$. Estimated 1985 $\mathrm{CO}_{2}$ emissions are as follows:

\begin{tabular}{lll}
$0 \mathrm{il}$ & $2.08 \mathrm{PgC} / \mathrm{yr}$ & $(40 \%)$ \\
Gas & $0.92 \mathrm{PgC} / \mathrm{yr}$ & $(18 \%)$ \\
Coal & $2.16 \mathrm{PgC} / \mathrm{yr}$ & $(42 \%)$ \\
\hline Total & $5.15 \mathrm{PgC} / \mathrm{yr}$ &
\end{tabular}

Source of data is DOE/EIA International Energy Annual 1985, DOE/EIA0219(85), Energy Information Agency, Washington, D.C. (1985).

2 Trabalka (1985), p.6.

3 Ibid. p.70. U.S. emissions grew at a slower 2.2 percent per year between 1950 and 1980.

4 This holds as an identity when changes are smal1. To demonstrate this define the following notation:

$$
\begin{aligned}
& Y=\text { GNP } \\
& E=\text { Energy } \\
& C=C 02 \text { Emissions. }
\end{aligned}
$$

It follows then that,

$$
C=(C / E)(E / Y) Y,
$$

and that therefore,

$$
\frac{d \ln C / d t}{C}=\frac{d \ln (C / E) / d t}{(C / E)}+\frac{d \ln (E / Y) / d t}{(E / Y)}+\frac{d \ln Y / d t}{Y}
$$

5 It is important to note that the HYDROCARB pre-scrubbing technology is as yet untried. The $\mathrm{CO}_{2}$ stack gas scrubbing technology is available. It is currently applied to produce commercial quantities of $\mathrm{CO}_{2}$. Deep 
sea disposal of $\mathrm{CO}_{2}$ is an untried technology. Technology cost estimates are discussed in the section on long-term energy supply options.

6 The heat rates for natural gas and coal fired boilers are similar but not identical. The annual average heat rate for natural gas fired power plants was $10,822 \mathrm{Btu} / \mathrm{kWh}_{\mathrm{e}}$ in 1985 as compared to $10,378 \mathrm{Btu} / \mathrm{kWh}$ e in coal fired power plants that year (DOE/EIA, 1987c). Heat rates for natural gas would be lower and similar to coal fired power plants, if used for base load power generation.

7 DOE/EIA, P.273 for heat rate. Energy to work equivalent of $3412 \mathrm{Btu} / \mathrm{kWh}$.

8 The term "energy efficiency" is used in this section interchangeably with the term "energy intensity" to refer to the relationship between an aggregate of energy use and an aggregate of activities. In general, we will reserve the term efficiency for use with specific processes and fuels. We depart in this section to be consistent with the specific terminology employed in NEPP.

9 The general growth rate calculation is shown below:

$$
r=\left(y_{t} / y_{0}\right)^{* *}(1 /(t-1))
$$

where: $\quad y=$ the variable undergoing annual growth (energy demand)

$r=$ annual growth rate for the variable $y$

$y_{t}=$ the value of $y$ in year $t$

$y_{0}=$ the value of $y$ in year 0 (the base year)

$t=$ the number of years from the base year at which the future forecast is determined.

( for NEPP - 26 yrs, WRI - 40 yrs)

This is the standard model for calculating constant periodic growth according to a geometric series. In this study, the value of $r$ above will be determined for the energy demand factors in the two models and then tabulated for comparison.

10 The base case used is DOE/EIA (1988a) in the case of Chandler et al. Total $\mathrm{CO}_{2}$ emissions associated with that case in the year 2000 are 1.59 $\mathrm{PgC/yr}$. Energy end-use conservation is estimated to reduce emissions to $1.24 \mathrm{PgC} / \mathrm{yr}$ and the introduction of advanced gas turbine technology is estimated by Williams (personal communication) to reduce emissions further to $1.19 \mathrm{PgC} / \mathrm{yr}$. These calculations are given in the table below: 
YEAR 2000 FORECAST OF ENERGY AND CO2 (Quads)

\begin{tabular}{|c|c|c|c|}
\hline $\begin{array}{l}\text { ENERGY SOURCE } \\
\text { Nuclear } \\
\text { Hydro } \\
\text { Coal } \\
\text { Oil } \\
\text { Natural Gas } \\
\text { Total }\end{array}$ & $\begin{array}{r}\frac{1987}{4.9} \\
3.3 \\
18.0 \\
32.6 \\
17.4 \\
76.2\end{array}$ & $\begin{array}{r}E I A \\
6.4 \\
4.1 \\
22.6 \\
36.3 \\
20.2 \\
89.6\end{array}$ & $\begin{array}{r}\text { ACEEE } \\
6.4 \\
4.1 \\
18.6 \\
29.1 \\
13.0 \\
71.2\end{array}$ \\
\hline
\end{tabular}

CO2 EMISSIONS

\begin{tabular}{|c|c|c|c|}
\hline $\begin{array}{l}\text { Nuclear } \\
\text { Hydro } \\
\text { Coal } \\
\text { Oil } \\
\text { Natural Gas } \\
\text { Total }\end{array}$ & $\begin{array}{l}0.00 \\
0.00 \\
0.45 \\
0.66 \\
0.25 \\
1.36\end{array}$ & $\begin{array}{l}0.00 \\
0.00 \\
0.57 \\
0.74 \\
0.29 \\
1.59\end{array}$ & $\begin{array}{l}0.00 \\
0.00 \\
0.47 \\
0.59 \\
0.19 \\
1.24\end{array}$ \\
\hline
\end{tabular}

Williams points out (personal communication) that these calculations are consistent with those in WRI.

Estimates of $\mathrm{CO}_{2}$ emissions reduction potential for $\mathrm{DOE} / \mathrm{OC}$ are based on conservation potential estimates applied to the NEPP forecast (Table 18) plus an additional reduction of $\mathrm{CO}_{2}$ emissions based on an increase in natural gas used in advanced turbines to generate power which is used to displace conventional coal fired power. Changes made to Table 18 are summarized in the following tables and notes:

\section{ENERGY USE BY FUEL AND SECTOR: 2010} quads

NUC \&

\begin{tabular}{|c|c|c|c|c|c|c|}
\hline $\begin{array}{l}\text { Residential } \\
\text { Commercial } \\
\text { Industrial } \\
\text { (Non-Energy Uses) } \\
\text { Transportation } \\
\text { Electric Utilities } \\
\text { Synfuels } \\
\text { Venting \& Flaring }\end{array}$ & $\begin{array}{r}\text { OIL } \\
0.9 \\
1.1 \\
7.8 \\
4.0 \\
14.7 \\
0.9 \\
-0.6 \\
0.4 \\
\end{array}$ & $\begin{array}{r}\text { GAS } \\
2.9 \\
2.5 \\
7.4 \\
0.9 \\
0.6 \\
6.6 \\
-0.3 \\
0.1 \\
\end{array}$ & $\begin{array}{r}\text { COAL } \\
0.1 \\
0.1 \\
4.3 \\
0.1 \\
0.0 \\
11.8 \\
1.6 \\
0.0 \\
\end{array}$ & $\begin{array}{r}\text { ELEC } \\
3.2 \\
2.8 \\
5.2 \\
0.0 \\
0.0 \\
-11.2 \\
0.0 \\
0.0 \\
\end{array}$ & $\begin{array}{r}\text { RENEW } \\
1.4 \\
0.7 \\
2.8 \\
0.0 \\
0.9 \\
16.2 \\
0.0 \\
0.0 \\
\end{array}$ & $\begin{array}{r}\text { TOTAL } \\
8.5 \\
7.1 \\
27.3 \\
5.0 \\
16.2 \\
35.5 \\
0.7 \\
0.5\end{array}$ \\
\hline $\begin{array}{l}\text { Total } \\
\text { Total (exc. wood) }\end{array}$ & $\begin{array}{l}24.8 \\
24.8\end{array}$ & $\begin{array}{l}19.7 \\
19.7\end{array}$ & $\begin{array}{l}17.8 \\
17.8\end{array}$ & $\begin{array}{l}-0.0 \\
-0.0\end{array}$ & $\begin{array}{l}21.9 \\
16.2\end{array}$ & \\
\hline
\end{tabular}


CO2 EMISSIONS BY FUEL AND SECTOR: 2010 $\mathrm{PgC} / \mathrm{yr}$

\begin{tabular}{|c|c|c|c|c|c|}
\hline & OIL & GAS & COAL & TOTAL & (Percent) \\
\hline Residential & $\overline{0.02}$ & $\overline{0.04}$ & $\overline{0.00}$ & $\overline{0.06}$ & $5 \%$ \\
\hline Commercial & 0.02 & 0.04 & 0.00 & 0.06 & $5 \%$ \\
\hline Industrial & 0.08 & 0.09 & 0.10 & 0.27 & $24 \%$ \\
\hline Transportation & 0.30 & 0.01 & 0.00 & 0.31 & $27 \%$ \\
\hline Electric Utilities & 0.02 & 0.10 & 0.30 & 0.41 & $36 \%$ \\
\hline Synfuels & -0.01 & -0.00 & 0.04 & 0.02 & $2 \%$ \\
\hline Venting \& Flaring & 0.01 & 0.00 & 0.00 & 0.01 & $1 \%$ \\
\hline Total & 0.43 & 0.27 & 0.44 & 1.15 & $100 \%$ \\
\hline
\end{tabular}

NOTES: ELEC=Electric, NUC \& RENEW= Nuclear Power and Renewable Energy. This scenario modifies the above scenario for the electric utilities sector. It adds enough gas (6.6-1.8 quads) to the electric utility sector to make total gas consumption (res+com+ind+trans+util) 20 quads. It then produces electricity using gas turbines at (.405 eff). It then replaces sufficient coal capacity at .3 eff. to keep 11.2 quads of total delivered power. Note that efficiencies include $10 \%$ transmission and distribution losses.

It is important to point out further that the percentage attribution to conservation versus the supply side are not independent of the order in which the technologies are introduced and also not independent of one another. If end-use technologies are introduced first, they can have a larger impact than if they are introduced second. This is because a reduction in end-use demand also reduces electric power fuel requirements. The scale of electric power generation that power technologies, e.g. gas turbines, is therefore smaller than were these technologies introduced first. This effect is limited in our calculations based on DOE (1987) because the total amount of natural gas is constrained to 20 quads. In this case, the introduction of end-use technologies reduces the demand for natural gas in the end-use sectors and therefore actually increases the conservation potential of gas turbine technologies.

It is interesting to point out that total coal demand by electric utilities is less in the modified DOE (1988) based scenarios in the year 2010 than it was in the year 1985 by $20 \%$. Such a reduction in coal use should not require the accelerated retirement of coal fired capacity. 
11 The direct effects of alternative unilateral reductions in U.S. $\mathrm{CO}_{2}$ emissions are given in the table below:

Reduction in Global Fossil Fuel $\mathrm{CO}_{2}$ Emissions

Under Alternative Reductions in U.S. Emissions From 1985 Levels

Without Corresponding $\mathrm{CO}_{2}$ Reduction Initiatives by Other Countries a

\begin{tabular}{|c|c|c|c|c|c|c|}
\hline \multirow[b]{2}{*}{$\begin{array}{l}\text { Year } \\
1985 \\
1990 \\
1995 \\
2000 \\
2005 \\
2010\end{array}$} & \multicolumn{2}{|c|}{$\begin{array}{c}\text { Reference } \\
\text { c02 Emissions }\end{array}$} & \multicolumn{4}{|c|}{ U.S. Emission Reduction } \\
\hline & $\begin{array}{c}(\mathrm{PgC} / \mathrm{yr}) \\
1.25 \\
1.40 \\
1.47 \\
1.55 \\
1.64 \\
1.73\end{array}$ & $\begin{array}{c}(\mathrm{PgC} / \mathrm{yr}) \\
5.7 \\
6.4 \\
6.7 \\
7.0 \\
7.5 \\
7.9\end{array}$ & $\begin{array}{l}-0 \% \mathrm{0} \\
0.0 \% \\
2.4 \% \\
3.3 \% \\
4.3 \% \\
5.2 \% \\
6.1 \%\end{array}$ & $\begin{array}{l}-10 \% \mathrm{e} \\
2.2 \% \\
4.3 \% \\
5.2 \% \\
6.0 \% \\
6.9 \% \\
7.7 \%\end{array}$ & $\begin{array}{r}-25 \% \\
5.5 \% \\
7.3 \% \\
8.0 \% \\
8.7 \% \\
9.4 \% \\
10.1 \%\end{array}$ & $\begin{array}{l}-50 \% 9 \\
11.0 \% \\
12.2 \% \\
12.6 \% \\
13.1 \% \\
13.6 \% \\
14.1 \%\end{array}$ \\
\hline
\end{tabular}

Notes:

a The percentage reduction in global emissions refers to the reference emission and not to 1985 emissions levels. Values calculated on the assumption that had the NEPP emissions been realized, the U.S. share of emissions would have been 0.22 . The resulting reduction in global emissions relative to the reference value is simply the product of 0.22 and the percentage reduction from NEPP forecast emissions to the target emissions

in each case.

b NEPP Reference Case

c Computed so as to maintain U.S. $\mathrm{CO}_{2}$ emissions at $22 \%$ of the global total. This emission is a reference value only.

d Assumes constant 1985 emissions 1985-2010.

e Assumes $10 \%$ reduction from 1985 emissions with that emission rate held constant 1985-2010.

$f$ Assumes $25 \%$ reduction from 1985 emissions with that emission rate held constant 1985-2010.

g Assumes $50 \%$ reduction from 1985 emissions with that emission rate held constant $1985-2010$. 


\section{TABLE NOTES}

Table 7:

Non-energy uses of fossil fuels which are not anticipated to be oxidized in the near term have been removed from total fuel uses. We have adopted conventions laid out in Marland and Rotty (1984). Specifically, we have assumed that $60 \%$ of the LPG and ethane from gas plants, $20 \%$ of the naphtha, $50 \%$ of the lubricants and none of the other non-fuel uses of petroleum such as asphalt, petroleum coke, and petrochemical feedstocks, are oxidized rapidly. For gas, none of the non-fuel uses is assumed to oxidize rapidly. For the years 1980 and 1985 non-fuel uses are taken from EIA (1986). For 1975 and 1970 they are taken from Marland and Rotty (1984). For earlier years we adopt the same assumption as Marland and Rotty (1984), that 0.0316 of natural gas use went to non-oxidizing uses. Coal is treated as if none of the non-fuel uses were oxidized rapidly. Actual values for 1980 and 1985 were taken from EIA (1986). For earlier years it is assumed that the fraction of coal not oxidized is the same as in 1980.

Table 11:

a All costs are in January 1986 U.S. dollars.

b Unit capital costs, efficiencies, and O\&M costs are EPRI estimates, for a bituminous coal-fired subcritical steam plant with flue gas desulfurization (EPRI, 1986).

c The assumed coal price is $\$ 1.73 / \mathrm{GJ}$, the average utility price projected for 1995 by the DOE/EIA (1987b).

d Reactor plant size, unit capital costs, and efficiencies are EPRI (1986) estimates. The two sets of capital costs are the current cost and an EPRI target for "improved" conditions--resulting from higher construction labor productivity, shorter construction period, streamlined licensing process, etc. The assumed nuclear fuel cycle cost is $\$ 0.81 / G J$, EPRI's projection for the period 1990-2000 (EPRI, 1986). The assumed 08M cost is the 1985 U.S. average for nuclear power plants DOE/EIA (1987a), twice as large as the EPRI estimate for new plants EPRI (1986).

e Based on the fuel's higher heating value and for operation at $100 \%$ load.

$f$ For a $6.1 \%$ real discount rate (recommended by EPRI, 1986), 30-year plant life, and $70 \%$ capacity factor. No taxes or tax incentives are included.

g The "current" combined cycle is two 75 MW GE Frame $7 E$ gas turbines plus an $86 \mathrm{MW}$ steam turbine; the "advanced" unit is a recently commercialized 135 MW GE Frame $7 F$ gas turbine plus a $70 \mathrm{MW}$ steam turbine. The combined cycle efficiencies are EPRI (1986) estimates; a GE analyst projects a $45 \%$ efficiency for the advanced combined cycle operating at a turbine inlet temperature of 2300 of (Brandt, 1986). 
Table 11 Notes Continued:

The STIG unit is a commercial steam-injected gas turbine based on the GE LM 5000 (L. Gelfand, Manager, Advanced Programs and Ventures, General Electric Marine and Industrial Division, Cincinnati, Ohio, personal communication, February 1987). The ISTIG unit is an intercooled steam-injected gas turbine under development, based on the LM 5000 (Larson and Williams, 1987 and PG\&E, 1984).

The assumed unit capital costs for STIG and the current combined cycle $(20 \%$ higher than for STIG) are from Soroka (1987). The unit capital cost for the advanced combined cycle is assumed to be the same as for current combined cycles. The assumed unit capital cost for ISTIG (the same as for STIG) is probably an overestimate, in light of the fact that with only minor modifications the output of STIG would more than double in being converted to ISTIG.

In all cases the assumed 0\&M costs are EPRI (1986) estimates for combined cycles, even though a Bechtel analys is indicates that steam-injected gas turbine systems offer inherent 0\&M cost savings compared to combined cycle units (Soroka, 1987).

h The average gas price for electric utilities was $\$ 2.22 / G J$ in 1986 .

$i$ The performance/cost values for combined cycles fired with oxygen-blown gasifiers are EPRI (1986) estimates for the Texaco gasifier. The corresponding numbers for systems using an air-blown gasifier are from a GE study exploring less costly, more energy-efficient alternatives to the Texaco gasifier (Corman, 1986).

SOURCE: Williams and Larson (1988), Table 1.

Table 24:

a A uniform activity indicator used for the denominator in the various sectors' energy intensity calculations, (quads/unit activity level), is not available. Choice of a particular activity indicator is arbitrary and is determined by available data from the two studies. Other footnotes to this table describe the units used in developing energy intensity values for the various sectors:

b Residential Sector Energy Intensity Measure: Quads used per million occupied dwellings.

c Commercial Sector Energy Intensity Measure: Quads used per billion square feet of commercial floor space.

d Industrial Sector Energy Intensity Measure: Quads used per billion dollars GNP. 
Table 24 Notes Continued:

e Transportation Sector Energy Intensity Measure: Billions of gallons of fuel per billion vehicle miles traveled. Figures used in transportation include only highway vehicles; the NEPP figures were obtained from a category entitled, "All Vehicles," while the WRI figures were listed under "Automobiles and Light Trucks." The WRI study listed another category entitled, "Intercity Truck Freight," in which the growth rate of the energy intensity was $-1.72 \%$ year over the same 40 -year period. It is uncertain whether or not this second category was included in the WRI figures.

Table 25:

a Historical Emissions.

b NEPP Reference Case forecast.

c NEPP High Efficiency Case.

d Extrapolation of the $2.5 \% / y r$ rate of reduction of $\mathrm{CO}_{2} / \mathrm{GNP}$ combined with NEPP Reference Case GNP forecast.

e Includes conservation potential only.

$f \quad$ First value refers to ACEEE forecast published in Chandler et al. (1988). Second value refers to additional $\mathrm{CO}_{2}$ emissions reductions possible by replacing some coal fired electric power with gas turbine electric power generation. Energy values provided by R.H. Williams in a personal communication.

g First value from Table 19. No account is taken of the potential for further reductions associated with electric power generation. The second value includes a calculation which increases total natural gas consumption to 20 quads and uses the increase to replace coal fired power generating capacity with advanced gas turbine technology. Gas turbines are assumed to be 0.405 efficient including transmission and distribution losses (0.45 efficiency at the busbar). Coal fired capacity is assumed to be 0.3 efficient including transmission and distribution losses.

$h$ WRI refers to the analysis of WRI.

$i$ First value refers to Cheng et al. (1986) energy intensity reduction only. Second value refers to combined effect of energy intensity reduction with accelerated introduction of nuclear power. 



\section{REFERENCES}

Applied Energy Services, Inc. March 7, (1986). Fossil2 Energy Policy Model Demand Sector Documentation, Volume 1 - Model Description. Applied Energy Services, Inc. Arlington VA.

Applied Energy Services, Inc. (September, 1986). Fossil2 Energy Policy Model Demand Sector Documentation, Volume 2 - Variable Documentation. Applied Energy Services, Inc. Arlington, VA.

Brandt, D.E. (1986). "Heavy-Duty Turbopower: the MS7001F. Mechanical Engineering. pp.28-36.

Carl, M.E. and Sheer, R.M. (1987). Energy Conservation Potential: A Review of Eight Studies, prepared for the Office of Conservation and the Office of Policy, Planning, and Analysis, U.S. Department of Energy, by Energetics, Inc., Columbia, MD (September).

Chandler, W.U., Geller, H.S. and Ledbetter, M.R. (1988). Energy Efficiency: A New Agenda. The American Council for an Energy-Efficient Economy, 1001 Connecticut Avenue, N.W., Washington, D.C. 20036. (July).

Cheng, H.C. (1988). Potential Reductions in U.S. CO2 Emissions in 1995 and 2010 by Technology Improvements in Electricity Generation and Transportation Sectors. Process Sciences Division, Department of Applied Science, Brookhaven National Laboratory, Upton, New York 11973.

Cheng, H.C., Steinberg, M. and Beller, M. (1985). Effects of Energy Technology on Global $\mathrm{CO}_{2}$ Emissions. TR030. DOE/NBB-0076. National Technical Information Service, U.S. Department of Commerce, Springfield Virginia 22161.

Corman, J.C. (1986). System Analysis of Simplified IGCC Plants. Report prepared for the U.S. DOE by GE corporation REsearch and Development. Schenectady, New York.

DOE (1985). National Energy Policy Plan Projections to 2010, DOE/PE-0029/3. National Technical Information Service, U.S. Department of Commerce, Springfield Virginia 22161.

DOE (1987). Energy Conservation: Multi-Year Plan FY 1989-93. U.S. Department of Energy, Office of Conservation, Washington, D.C. 20585.

DOE (1988). An Assessment of the Natural Gas Resource Base of the United States, DOE/W/31109-H1. National Technical Information Service, U.S. Department of Commerce, Springfield Virginia 22161.

DOE/EIA (1987a). Historical Plant Cost and Annual Production Expenses for Selected Electric PTants 1985. DOE/EIA-0455(85). National Technical Information Service, U.S. Department of Commerce, Springfield Virginia 22161.

DOE/EIA (1987b). Annual Energy Outlook 1986, with Projections to 2000. DOE/EIA-0383(86). National Technical Information Service, U.S. Department of Commerce, Springfield Virginia 22161. 
DOE/EIA (1987c). Annual Energy Review 1986. DOE/EIA-0384(86). National Technical Information Service, U.S. Department of Commerce, Springfield Virginia 22161.

DOE/EIA (1988a). Annual Energy Outlook 1987. DOE/EIA-0383(87). National Technical Information Service, U.S. Department of Commerce, Springfield Virginia 22161.

DOE/EIA (1988b). Annual Energy Review 1987. DOE/EIA-0384(87). National Technical Information Service, U.S. Department of Commerce, Springfield Virginia 22161.

Edmonds, J. and Reilly, J. (1983). "Global Energy and $\mathrm{CO}_{2}$ to 2050." The Energy Journal $4(3): 21-47$.

Edmonds, J. and J. Reilly (1985). Global Energy: Assessing the Future. Oxford University Press, New York.

Edmonds, J.A., Reilly, J.M., Trabalka, J.R., and Reichle, D.E. (1984). An Analysis of Possible Future Atmospheric Retention of Fossil Fuel $\mathrm{CO}_{2}$. TR013, DOE/OR/21400-1. National Technical Information Service, U.S. Department of Commerce, Springfield Virginia 22161.

EPRI (1986). Technical Assessment Guide, 1: Electricity Supply 1986. Palo Alto, CA: Electric Power Research Institute.

ERAB (1988). R\&D Initiatives for Energy Competitiveness, A Report of the Energy Research Advisory Board (ERAB) to the United States Department of Energy. DOE/S-0061. National Technical Information Service, U.S. Department of Commerce, Springfield Virginia 22161.

Goldemberg, J., Johansson, T.B., Reddy, A.K.N., and William, R.H. (1987). Energy for a Sustainable World. Wiley-Easton, New Delhi, India.

Haefele, W. (1981). Energy in a Finite World. Ballinger Publishing Company, Cambridge MA.

Kellogg, M.A., Edmonds, J.A., Scott, M.J., and Pomykala, J.S. (1987). Key Statistics Related to $\mathrm{CO}_{2}$ Emissions: Significant Contributing Countries. Pacific Northwest Laboratory Report, PNL-6238. Richland WA.

Larson, E.D. and Williams, R.H. (1987). "Steam-Injected Gas Turbines," ASME Journal of Engineering for gas Turbines and Power.

Marland, G. (1983). "Carbon Dioxide Emission Rates for Conventional and Synthetic Fuels," Energy, $\underline{8}(12): 981-992$.

Marland, G. and Rotty, R.M. (1984). "Carbon Dioxide Emissions From Fossil Fuels: A Procedure for Estimation and Results for 1950-1982." Tellus $\underline{36 B}(4): 232-261$. 
Moore, T. (1988). "Utility Turbines for the 1990's." EPRI Journal:5-13. (Apri1/May).

Ogden, J.M. and Williams, R.H. (1983). Hydrogen and the Revolution in Amorphous Silicon Solar Cell Technology, Draft paper, Center for Energy and Environmental Studies, Princeton University, Princeton, NJ 08544.

PG\&E (Engineering Department, Pacific Gas and Electric Company) (1984). Scoping Study: LM5000 Steam-Injected Gas Turbine. Based on work performed by the Marine and Industrial Engine Projects Department (Evendale, Ohio) of the General Electric Company.

Soroka, G.E. (Bechtel Eastern Power Corp.). (1987). Modular Remotely Operated Fully Steam-Injected Plant for Utility Application. Paper presented at the Cogen-Turbo Conference. Montreux, Switzerland: American Society of Mechanical Engineers.

Steinberg, M. (1983). An Analysis of Concepts for Controlling Atmospheric Carbon Dioxide. TRO07, DOE/CH/00016-1. (December).

Steinberg, M. and Cheng, H.C. (1987). Advanced Technologies for Reducing C02 Emissions. Document No. 40730, Brookhaven National Laboratory, Brookhaven, NY.

Strauss, C.H., et al. (1988). "An Input Analysis of Multiple Rotation SRIC Biomass Plantation", paper presented at the 1988 Annual Solar Technologies conference, Cambridge MA.

Trabalka, J. (ed.) (1985). Atmospheric Carbon Dioxide and the Global Carbon Cycle. DOE/ER-0239. National Technical Information Service, U.S. Department of Commerce, Springfield Virginia 22161.

Williams, R.H. and Larson, E.D. (1987). "Materials, Affluence, and Industrial Energy Use," Annual Review of Energy 1987. 12:99-144.

Williams, R.H. and Larson, E.D. (1988). Aeroderivative Turbines for Stationary Power. PU/CEES Report No.226, Center for Energy and Environmental Studies, Princeton University, Princeton, NJ 08544. 


\section{ACKNOWLEDGMENTS}

The authors of this report owe a great debt to a number of people. Fred Koomanoff is responsible for conceiving this study, supporting the efforts of the researchers and encouraging the enterprise steadfastly from its inception. Kenneth Friedman worked throughout the course of the project, as a technical advisor, editor, sponsor and counselor. The quality of this report is markedly improved as a result of his participation. Alex Haynes, provided valuable comments and made it possible for Frances Wood to participate in the Roundtable process. Gregg Marland at the Oak Ridge National Laboratory was tirelessly willing to confer with the authors, review drafts, check numerical calculations, and generally make the authors look good throughout the course of this study. We are most appreciative. Bob Williams also provided countless hours of time and effort educating, providing technical input, and consulting on various earlier drafts along the way. In addition, six people: Marc Ross, University of Michigan; Henry Kelley, Office of Technology Assessment; Harvey Major, U.S. Department of Energy; Bill Chandler, Pacific Northwest Laboratory; Frances Wood, AES; and Bob Williams, Princeton University, joined the authors in a Roundtable format to discuss technical issues surrounding the technical feasibility and cost of reducing U.S. $\mathrm{CO}_{2}$ emissions in the period to 2010. We are indebted to these people for their counsel.

We are indebted to Hadi Dowlatabadi and Joel Darmstadter, both of Resources for the Future, for their technical review of the research and various of earlier drafts of the report. Art Rosenfeld, Lawrence Berkeley Laboratory, also provided the authors with reviews and insights. We are especially grateful to several reviewers of this paper who took time out from busy schedules to work with us to improve the report's quality including external reviewers: Tom Bath, Rosina Bierbaum, Bob Fri, Ted Harris, Marvin Miller, Leonard Levin, Ralph Perhac, Steve Piccot, Steve Schneider and Don Wuebbles; and U.S. Department of Energy reviewers: Dick Holt, Bob Kane, Ron Loose, Tom Werner, Ted Williams, Barry Williamson and Rick Bradley.

Within the Pacific Northwest Laboratory, Bill Chandler, Mike Scott, Joe Roop, Nancy Moore, Sean McDonald, and Bruce Kinzey all reviewed earlier drafts of this report. Their suggestions and comments have improved the quality of the document immeasurably.

Finally, we are grateful to the Carbon Dioxide Research Division in the Office of Energy Research, the Office of Conservation and the Office of Energy Policy all in the U.S. Department of Energy, for supporting various portions of this effort.

While others may have contributed unstintingly to our efforts, the authors nevertheless take credit (and responsibility) for the technical and intellectual content of this report. 